\title{
THE
}

\section{LIFE OF THE YELLOWSTONE BEAVER}

BY

EDWAFD R. WARREN

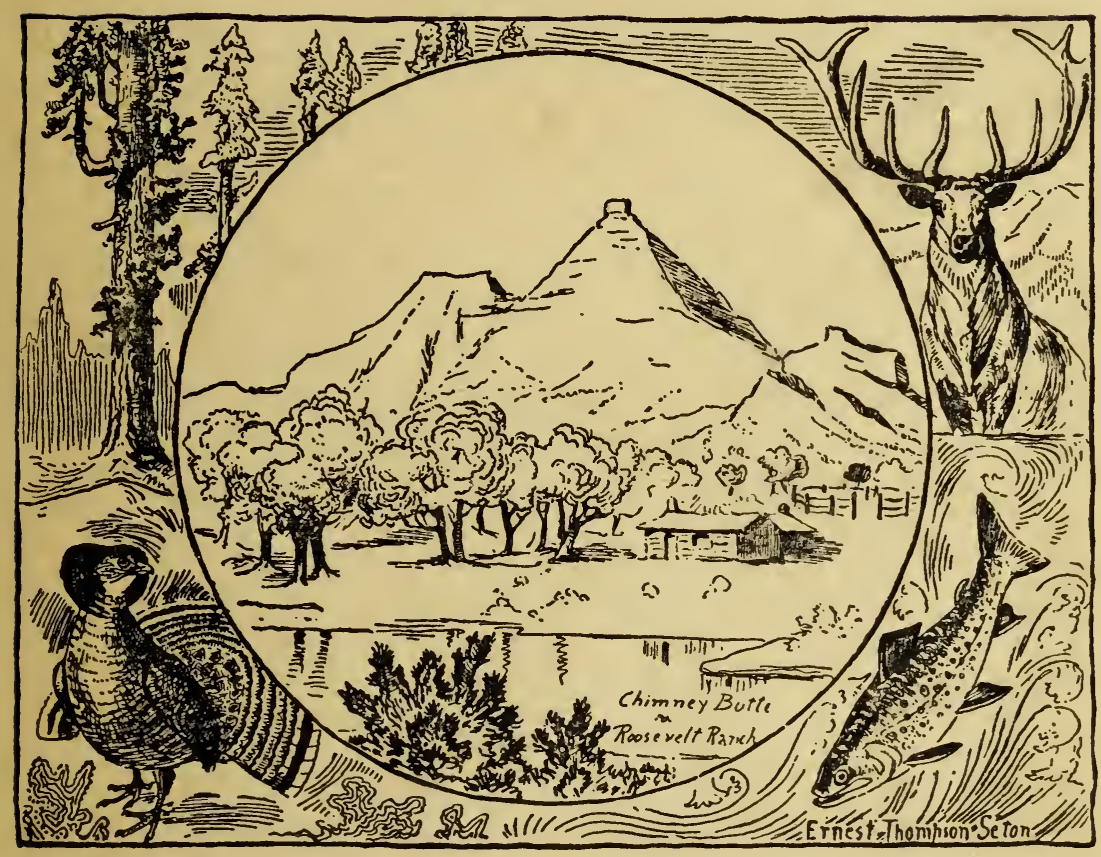

Roosevelt Wild Life Forest Experiment Station, Dr. Charles C. Adams, Director,

The New York State College of Forestry, Syracuse, N. Y.

Reprinted from the Roosevelt Wild Life Bulletin, Vol. I, No. 2, pp. $187-222,1922$ 


\title{
THE LIFE OF THE YELLOWSTONE BEAVER*
}

\author{
By Edward R. Warren \\ Collaborator, Roosevelt Field Naturalist, The Roosevelt Wild Life \\ Forest Experiment Station, Syracuse, New York
}

\section{Contents}

I. Why Study Beavers, and Where?

2. Food of the Beaver.

3. Beaver Engineering.

4. Life History, Other Habits, and Enemies.

5. Value of Beaver to the Park Visitor.

6. References to Literature.

\section{Why Study Beavers, and Where?}

If I were to judge from my experience at Camp Roosevelt, in the northeastern part of the Yellowstone National Park, during the past summer, no animal except the bear arouses so much interest on the part of the park visitors as the beaver. Within fifteen minutes' walk from the camp, near the bridge over the Yellowstone River, and close beside the Cooke City road, is a fine series of small beaver ponds (figure 37). Hardly an evening passed during the summer but anywhere from half a dozen to thirty people thought it well worth while to walk down there and spend an hour or more watching these fascinating animals, which are obliging enough to go about their usual activities almost oblivious to the interested observers lined up upon the bank beside the road. Here one can observe not only the

* This preliminary account of the Yellowstone beaver is the first of a series of papers on the wild life of the Yellowstone National Park which have been made possible by gifts to this Memorial Station from joint friends of Theodore Roosevelt and of wild life conservation. The initial aid for this plan came from Mr. Howard H. Hays, President of the Yellowstone Park Camps Company. These studies were made with the approval of Hon. Stephen T. Mather, Director of the National Park Service, and with the approval and hearty cooperation of Mr. Horace M. Albright, Superintendent of the Yellowstone National P'ark, and of Mr. M. P. Skinner, Park Naturalist. Mr. Warren, a very competent field naturalist, contributed his services, and he was aided by his volunteer assistant, Mr. Ellis L. Spackman, Jr. I gladly avail myself of this opportunity, on behalf of the Roosevelt Wild Life Station, to thank these men most heartily for their very substantial and generous contributions.- The Director. 
ponds, dams, lodges and all stages of felled trees and stumps, but even the beavers themselves swimming about in the water, crawling over the dams, cutting aspen branches, and busily and audibly eating the bark. If one is careful, by refraining from making quick movements and unusual sounds, so as not to disturb the animals, the opportunities for observation are excellent. Indeed, there are few places in America, even in remote regions, where such opportunities are equalled.

The park visitors asked me many questions regarding the beaver, and the following account answers some of these questions of general interest about them as well as summarizes the results of my own studies conducted in the vicinity of this Camp and at Yanceys, where in I897 and again in 1912, Mr. Ernest Thompson Seton conducted observations which were published in his books "Wild Animals at Home" and "Life Histories of Northern Animals."

The region is a very favorable one for beavers and contains several colonies of special interest. Each of the colonies was surveyed and mapped, to show the relation of the various ponds to one another. The dams were measured, and notes taken as to their construction; and as far as possible the lodges were studied, although most of them were inaccessible, and I did not feel justified in breaking into any of those which I could reach. I measured many stumps to find their height; many more were examined to see on which side they had been cut; and notes were taken as to the direction in which a tree had fallen, with reference to the deepest cut. Evenings were spent in watching the animals themselves and gleaning what information I could as to their ways. In short, an attempt was made to secure as much information as possible concerning the life history of the animals.

In my work about Camp Roosevelt during the summer of I92 I I examined no less than eight areas of beaver ponds and dams, as follows :

( I) Beside the Cooke City road, near the Yellowstone River bridge;

(2) South Fork of Elk Creek, from the Petrified Tree to Yanceys;

(3) North Fork of Elk Creek, and bench between the forks, west of Yanceys;

(4) Near Crescent Hill;

(5) Along Tower Creek, about two miles above Tower Fall:

(6) Lost Creek, above the Fall;

(7) Lost Lake, on the plateau above Camp Roosevelt;

(8) The Yancey Meadows. 


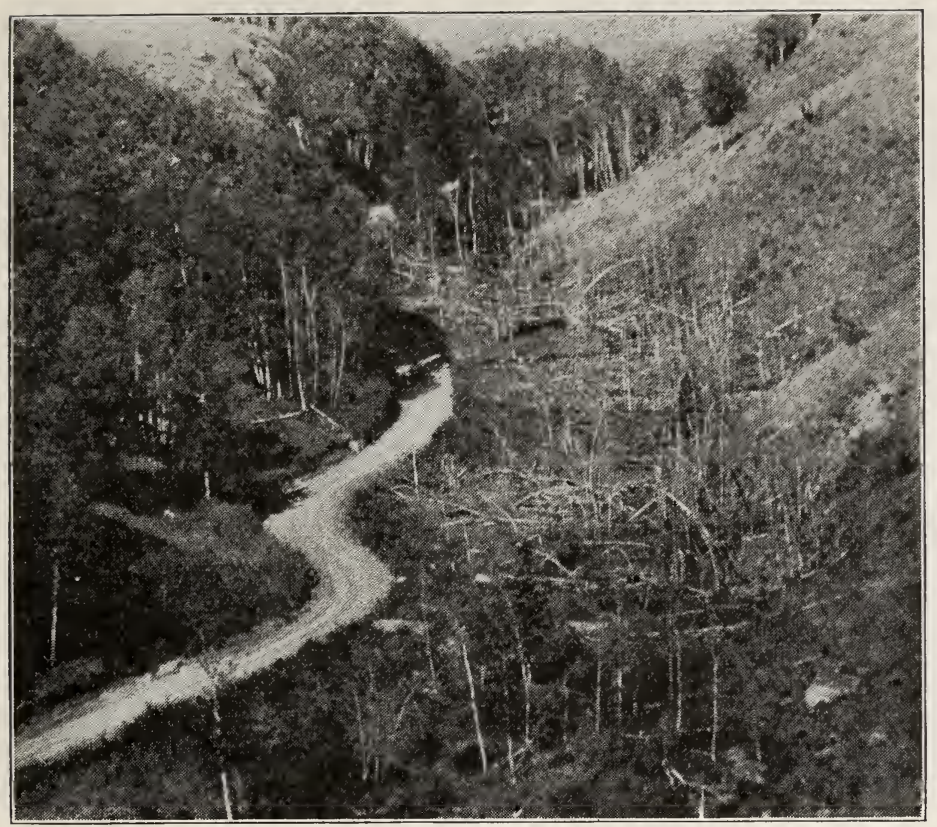

Fig. 37. The series of ponds beside Cooke City road near Camp Roosevelt, Yellowstone National Park. Taken from slope of Junction Butte above Yellowstone River bridge, showing location of ponds, large aspen grove on hillside, and the grove destroyed along the stream.

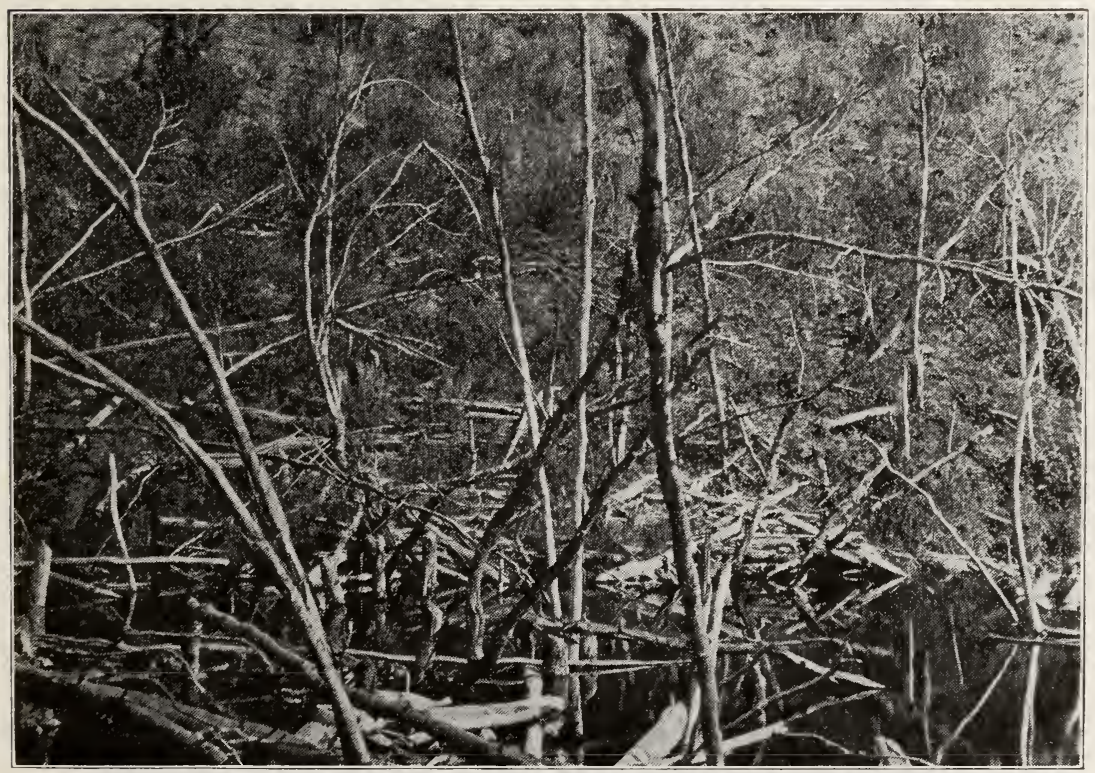

Fig. 38. Pond No. 2 beside Cooke City road, showing log-piles protecting the entrances to burrows. These log-piles may in time become lodges. 


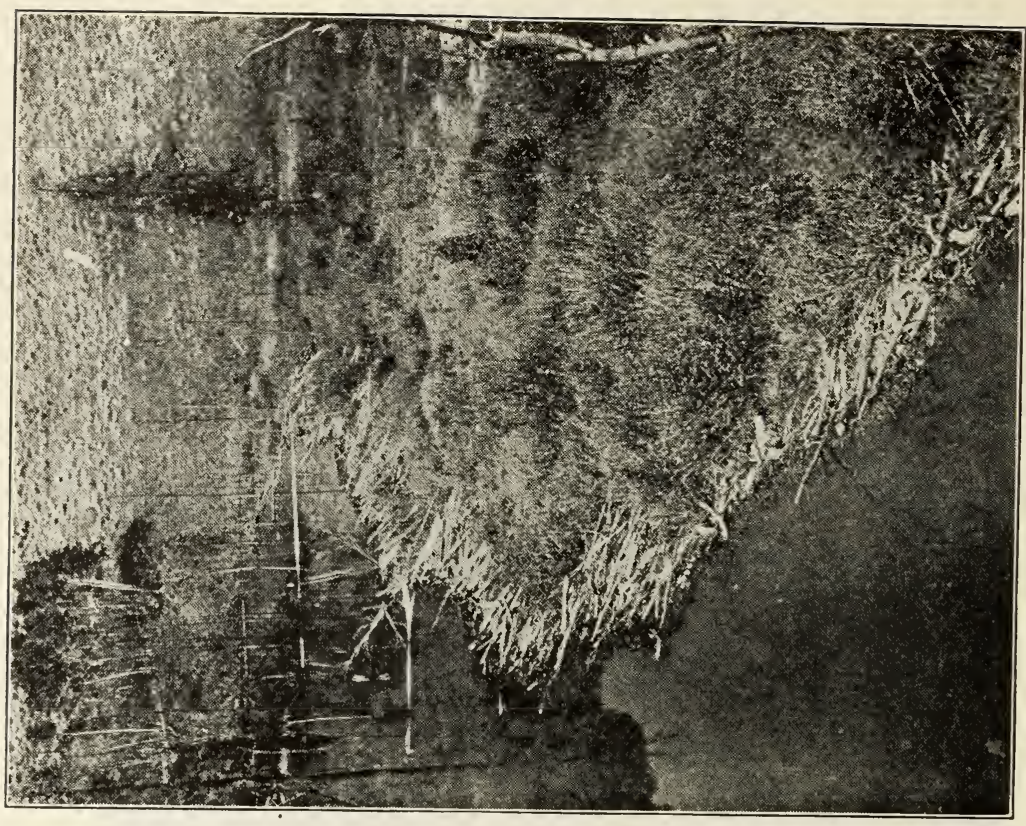

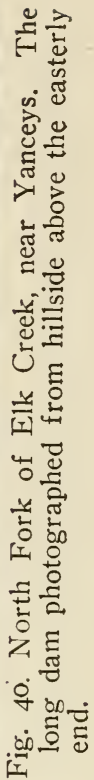

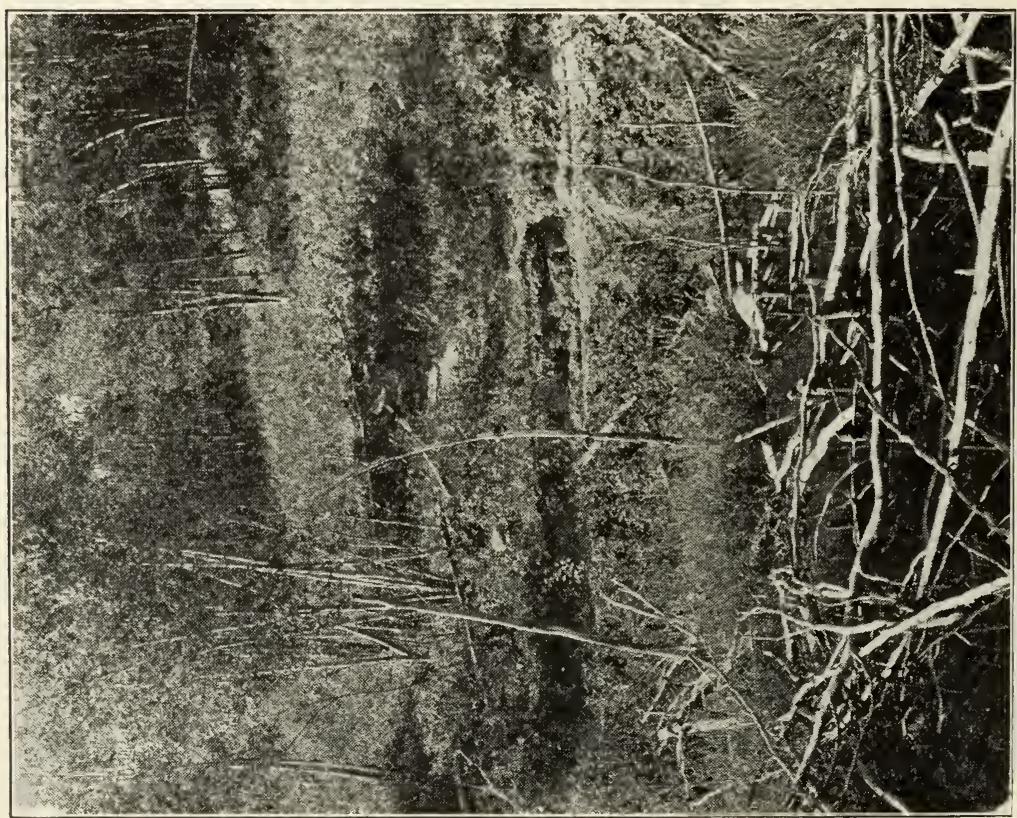

$\begin{array}{ll}4 & 0 \\ 0 & 0 \\ 0 & 0\end{array}$

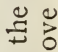

in 5

요

过

क

콣얼

- 0

$=0$

" స

\pm .

ธे ธี․ㅠ

ช

ऐัँ

은을

동

-

ले $\Rightarrow \frac{\mathscr{y}}{\pi}$ ००:

国 
These localities, together with a number of smaller ponds near by, harbor many colonies of beaver and represent a great variety of conditions. They are all easily accessible to the tourist by either roads or trails.

Colony near Yellowstone Bridge. The group of ponds parallelling the Cooke City road, near the Yellowstone Bridge (figure 37) is the one which visitors to Camp Roosevelt are most likely to see. If they do not make a special visit to the ponds they are almost sure to pass them on the way to the Yellowstone or Lamar rivers on fishing trips. Therefore a somewhat detailed account of them may not be out of place here. Mr. M. P. Skinner, the Park Naturalist, informs me that there were no beaver at this place ten years ago, so that all the work here has been done within that period of time. Here is a steep, narrow gulch, with a small stream of water, and formerly densely. set with aspens, along which have been constructed about twenty dams of various lengths, making a series of ponds which form a continuous waterway for several hundred feet. There are two lodges, and in one pond beaver were living in burrows whose entrances were protected by log-piles (figure 38 ). In this pond there were at least three beavers, an adult and two yearlings. Quite possibly there may also have been another adult. In one of the lodges were 2 adults, 3 yearlings, and 3 of the season's youngsters.

A question often asked is: Why do the beavers have so many ponds? There are several reasons for this. In the first place, these ponds were most probably not all built at once, but successively, those lowest downstream first. As the green aspens growing in the gulch and on the hillside were cut down and used for food, the animals had to move upstream to get nearer the food supply and so more dams were built. A beaver always prefers to travel in the water when it can; it is too much at the mercy of its enemies when on land, and also it can float sticks along a pond to the dam, drag them over the next to the pond below, and thus take them wherever desired. As practically all the green aspens in this gulch near the water as well as on the adjoining hillside are now cut, there is but little available food unless the animals go some distance above the uppermost ponds, where the space is too narrow and the slope too steep to make sizable pools. They do appear, however, to be working that way. Their other alternative is to go across the road to the large grove on the hillside above, and opposite the ponds (figure 39). They have cut down some trees there, but it is a dangerous 
place as they are exposed to attack while going to and fro. It was reported to me that one beaver had been killed there this season by some animal. This large grove should afford a supply of food for some years to come. I am interested to see what will be the outcome there, so I have marked the stumps of the trees cut by beaver, over 300 in all, by pounding the end of a half-inch iron pipe into them, making a circular mark in the wood. This will enable a future observer to identify the new cuttings.

Another use of a series of ponds is the protection which they give one another in times of high water. A dam backs water up against the dam above, strengthening it and helping it to resist increased pressures, while the ponds and dams still farther above, by holding back the flood water, distribute it more evenly and relieve the ponds below. To man, beaver ponds are useful in conserving the water supply, retaining much of the rain and snow which would otherwise pass off at once and go to waste.

South Fork of Elk Creek. A mile from Camp Roosevelt along the main highway, a road branches off to the Petrified Tree. Along this road one is immediately interested by the series of beaver ponds and the belt of tall dead timber in the ravine below. A fine forest sweeps up the slope beyond. The dead timber was killed by flooding as the result of a series of beaver dams built along the small stream in recent years. The area was practically abandoned after the beavers had used up all the aspens nearly to the head of the ravine. They are still at work intermittently on the few remaining large aspens in the swale opposite the Petrified Tree; but little or no effort is made to keep in repair the works below. The ravine is a tangle of silty ponds and grass-grown dams, through which many sluices and channels drain the water. Apparently the beavers use it chiefly as a highway now.

Lower down on the South Fork, in the forest just above the Yancey cabins, is a newer series of ponds and dams; but the same process of flooding the spruce flat and using up the aspen is going on steadily, and by and by the occupants will have to seek new homes. Whether the colony there migrated from the upper part of the stream or from some other locality is an interesting question.

North Fork of Elk Creek. Other groups of ponds which at least some of the visitors see, are those on the North Fork of Elk Creek. to the west of Yanceys, and on the high flat between the North and South Forks. In the former group is a very long dam, 350 feet in 


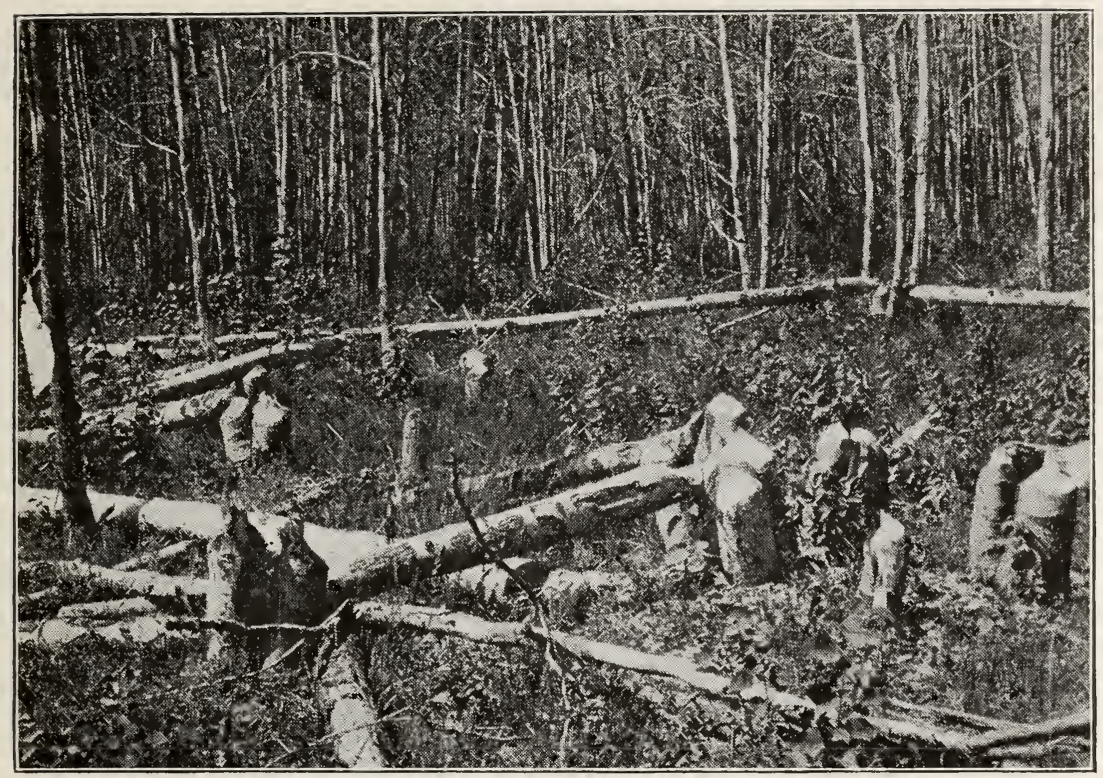

Fig. 4I. Freshly cut aspen logs, near pond on bench above Yanceys, August Io, I921. These trees are about 6 to Io inches in diameter.

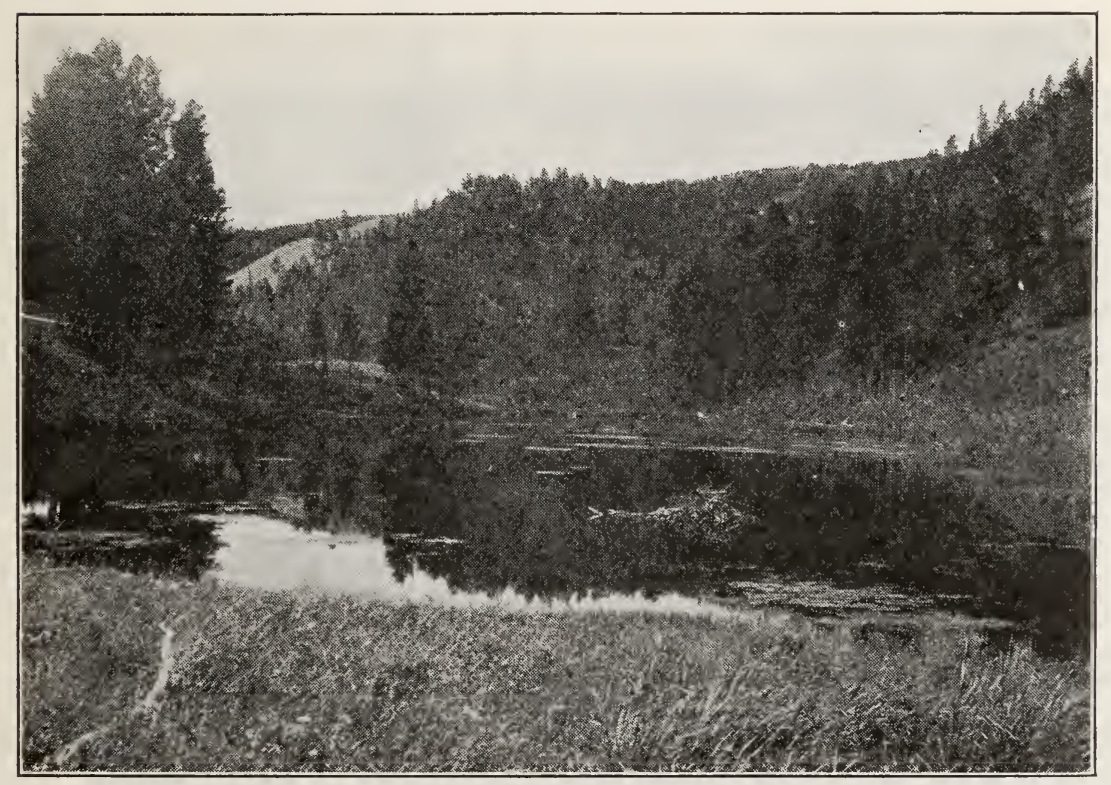

Fig. 42. The large pond at Crescent Hill; view from the upper end, showing beaver lodge and fringe of dead aspen. 

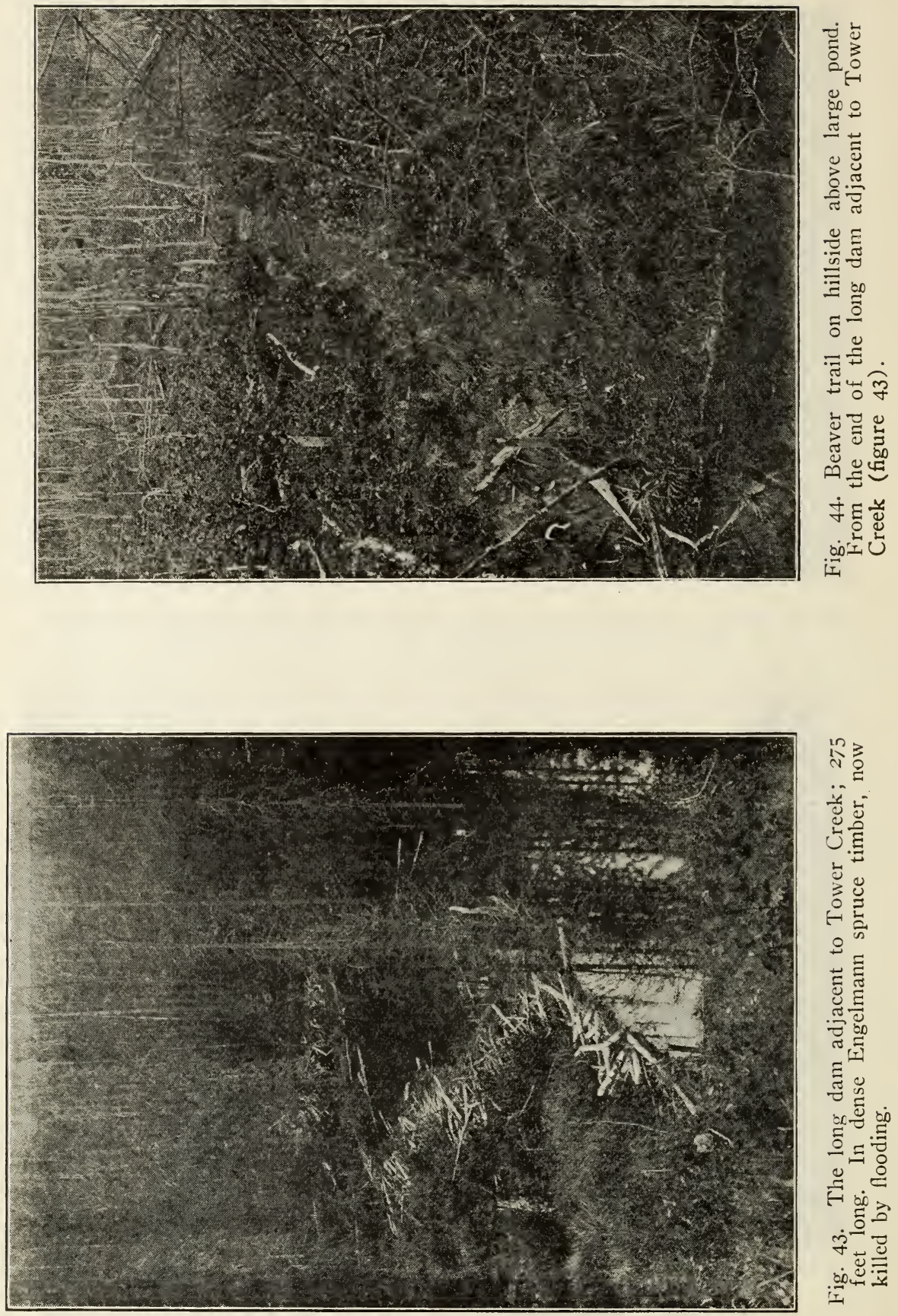

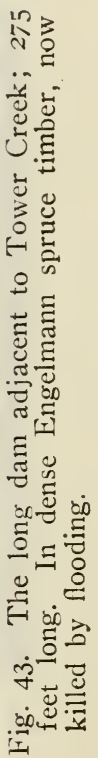


length (figure 40). In spite of the great length of dam the pond is not much more than Ioo feet wide. It contains a medium-sized, typically shaped lodge. Below this dam is another, the pond belonging to which is nearly filled up with silt, and much of it grown up to grass and willows, - a good example on a small scale of the making of a beaver meadow. And below this dam, strung along the creek for nearly half a mile, are no less than thirteen very old dams. Some of those farthest down the stream are being partially rebuilt and new ponds are forming.

Above the large dam is another 250 feet in length. The pond originally formed by this has been drained by a tunnel through the dam at the level of the water in the pond below. Above this is the unusual occurrence of a double series of ponds and dams. The easterly one, of five ponds, takes its water from flat, swampy ground. The westerly group of nine, a series of small ponds, is on the stream itself.

On the high flat between the North and South Forks is a small stream along whose narrow gulley the beavers have long since destroyed all the aspen nearly to its source, their disintegrating dams now alone remaining. This little stream is fed by cold springs in a dense old Engelmann spruce woods, along whose margin are fine mature groves of aspen. The beavers have now dammed the brooklet clear to the borders of the spruce bog, and a very interesting point to notice here is that the evaporation from the large pond seems to nearly balance the inflow, so that no water flows over the dam. If the flow of water into the pond does increase, from heavy rains for instance, the beavers at once build up the dam a bit higher, utilizing every drop of water. This largest pond contains two lodges. Many aspens have been freshly cut in a fine grove close along the shore (figure $4 \mathrm{I}$ ). In the marshy ground above, several small ponds have been dug out and dams built of mud during the past season, as well as more typical dams. In one of these ponds a small lodge was constructed between August Io and September 4, and aspen brush stored beside it.

Beaver Ponds near Crescent Hill. These are located in the beautiful region at the very head of the North Fork of Elk Creek, easily reached on horseback or on foot. The largest of the ponds (figure 42 ), at the foot of the Crescent Hill cliffs, lies in a perfect setting of forested hills and open grassy valleys. Most of the nearby aspen has been cut, but the beavers keep the dam in fair repair, so 
as to maintain a water highway at least, and forage farther and farther away. Over the divide from this pond is another large one, without visible outlet or inlet, where much fresh felling of aspen is going on. The trail to the lower Yellowstone River traverses the shores of this attractive pond.

The Tower Creek Works. Two miles above Tower Fall, and adjacent to the Creek, are some fine beaver works we.1 worth a visit by anyone interested in the subject. Here is a dam 275 feet long (figure 43) making a good sized pond, which contains a dense grove of large spruce killed by flooding. This pond is on the first flat or terrace above the creek, and receives its water supply from a very large spring a short distance above. Between this pond and the spring are many small ponds, and there are more below the large dam. Doubtless when the winter snows are melting and Tower Creek is high, it overflows this flat and floods these ponds. There is a giant beaver lodge in the midst of the heavily timbered flat (figure 6I).

The fact that all of the works here are on a large scale makes them of especial interest. The narrow and very deep ravine running nearly east and west, resulting in very different types of forest on the north and south slopes, has had the effect of confining the beaver cuttings to the broad aspen slope of southern exposure. Therefore the beaver runways, slicles and canals are especially marked and elaborate there. Figure 4 shows one of the steep and wellworn slides down which the heavers drag their loads of aspen from the open groves above, to the nearest corner of the big pond (indicated in figure 43 ).

On Carnelian Creek, tributary to Tower Creek, a pretty bit of engineering work was found. At a bend of the stream was a portion of an old clam, extending perhaps half way across. A low extension had been added to it, carrying it enough farther along to deflect part of the water onto the level bank of the stream, which was quite low at this place (figure 6o). This water supplied a series of three sizable ponds on the flat, the lowermost of which was several feet above the creek level at that point.

Lost Creek, Above the Fall. On the plateau above Camp Roosevelt the beavers are very active, and their dams in all stages of construction and disintegration indicate many years of habitation there. There are three ponds now in use, one of these containing three houses (figure 45); and some distance above is a newer group of 


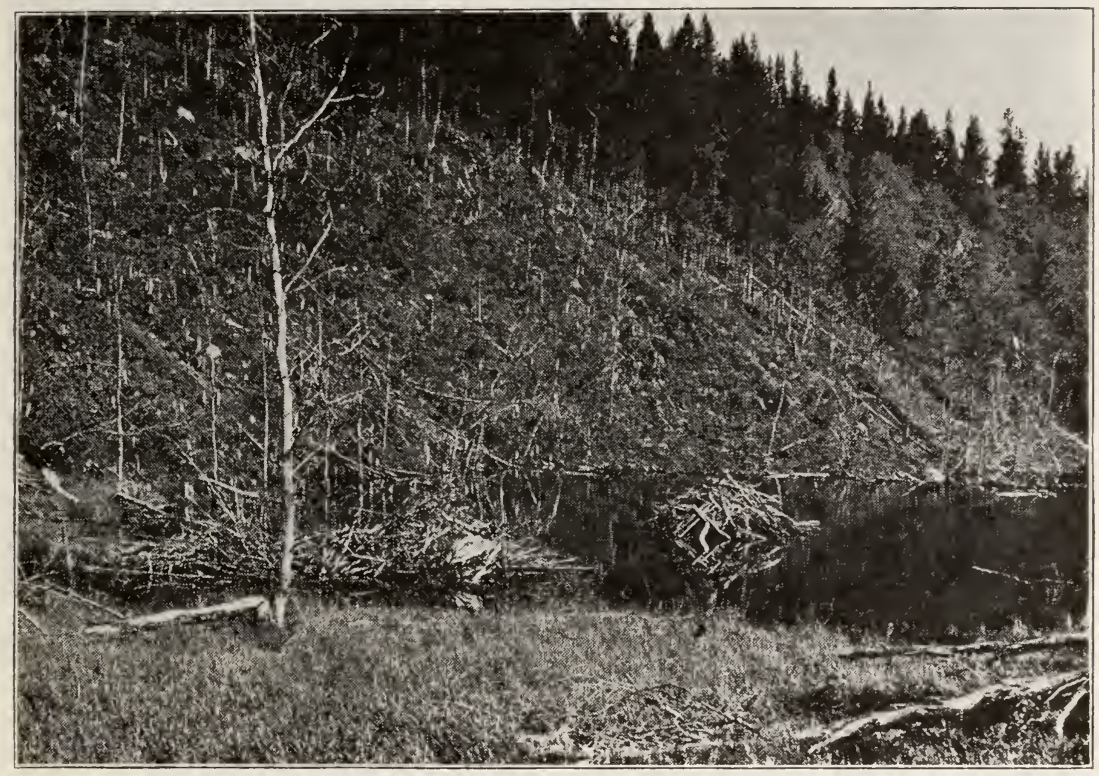

Fig. 45. Pond on Lost Creek with three lodges; also showing steep hillside with aspen stumps, denuded to the edge of the lodgepole pine forest. I75 feet from the pond.

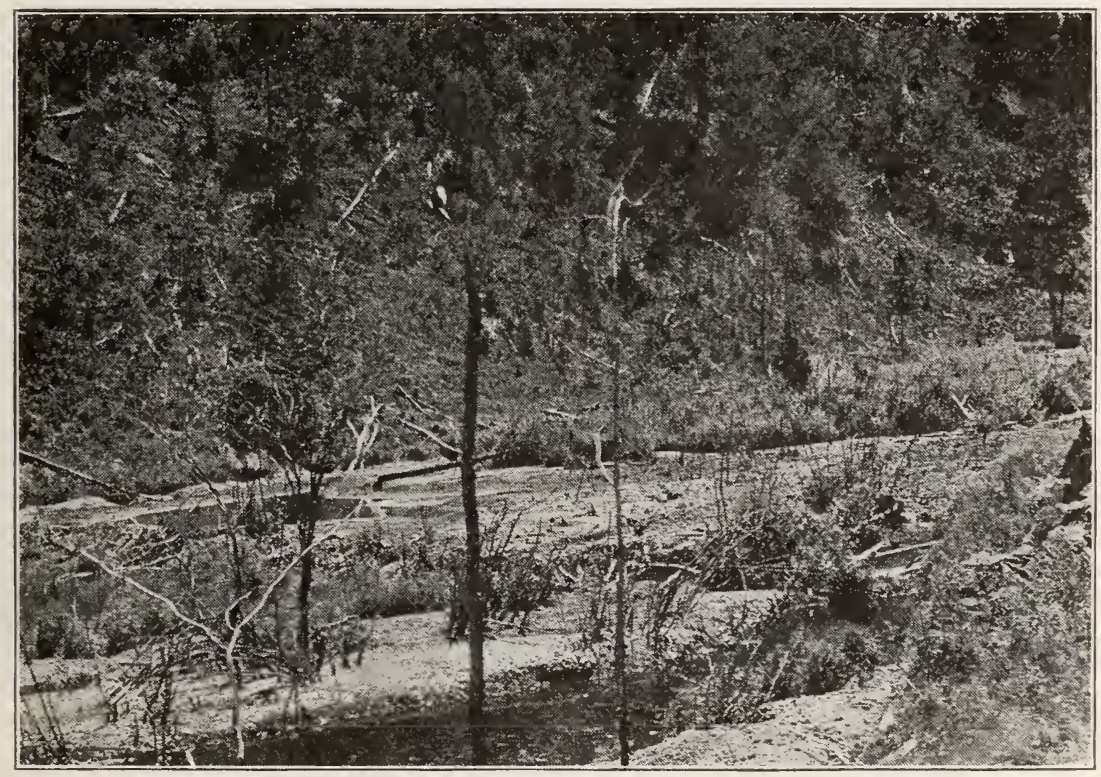

Fig. 46. Pond No. I4 on Lost Creek, showing gravel washed in. Illustrating how an abandoned pond may become filled with silt and débris. 


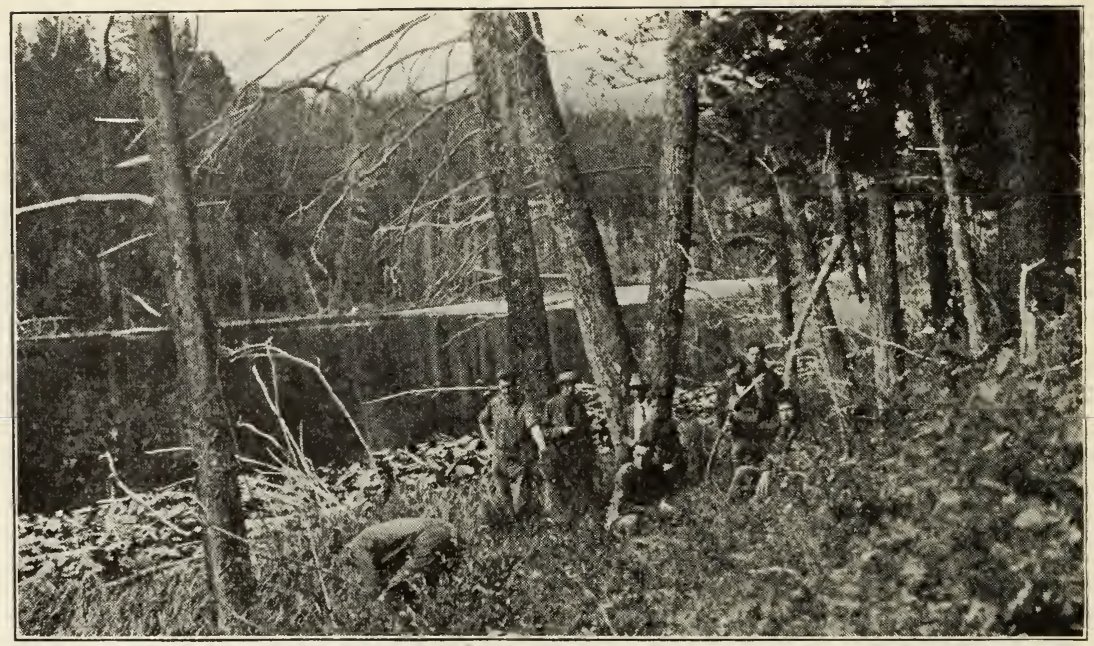

Fig. 47. Lost Lake, near Camp Roosevelt. A party of naturalists and boys from the Forest and Trail Camp on a beaver study excursion.

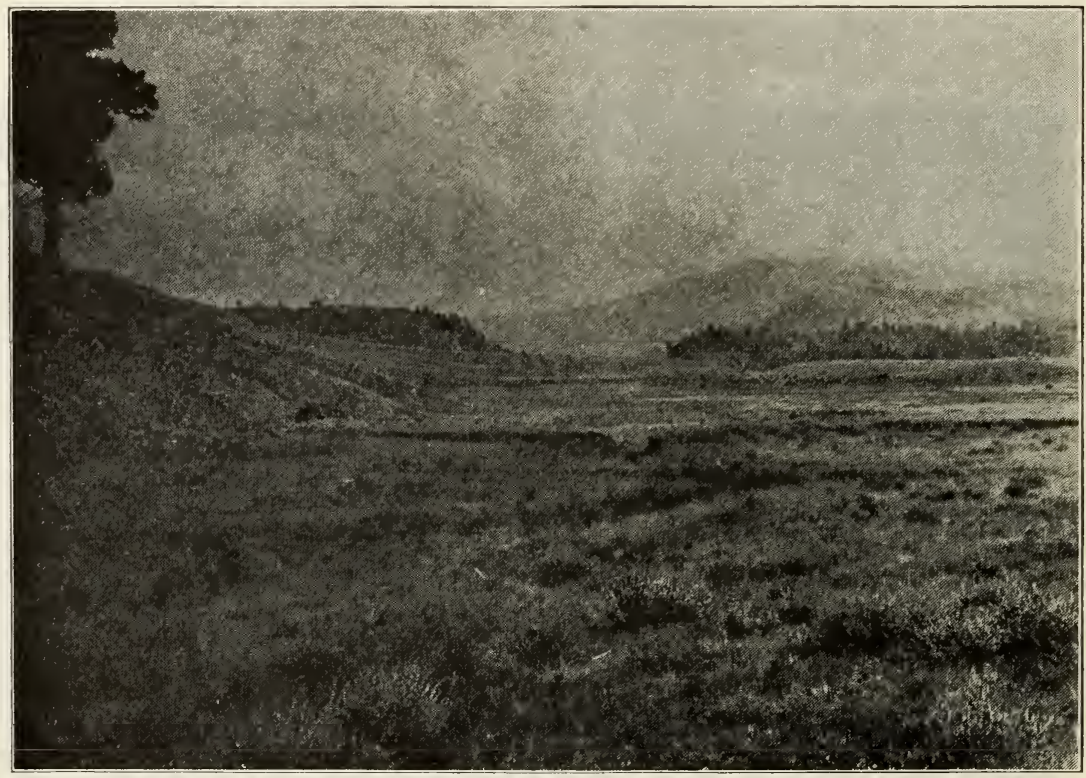

Fig. 48. Upper beaver meadows on Lost Creek, above Yanceys, showing old dam. These were large ponds when Ernest Thompson Seton studied them in 1807 . 
four small ponds. Figure 45 shows how high and steep a slope the beaver will denude of its aspen growth; and figure 46 tells the story of the silting up of beaver ponds as a result of spring freshets and summer thunder storms.

One wonders at first how the beavers, clumsy enough on land, ever reached the upper creek waters, for the high Lost Creek Fall drops sheer into a deep gorge hemmed in by perpendicular cliffs. But the creatures find their way to the plateau by other drainage lines, doubtless from Elk Creek on the north and the headwaters of some branches of Tower Creek on the south.

Lost Lake. This is an exquisite little lake (figure 47) amid the hills on the heights back of Camp Roosevelt, and readily reached by a steep footpath through the lodgepole pine forest. It is long and narrow, with both ends grown up to thick grass and the margins dense with luxuriant yellow water lilies. Its shores pitch sharply to considerable depths, soundings of 48 feet being obtained in it. It is a spring-fed ravine lake, raised somewhat by the old, low beaver dam near its rock-rim outlet at the margin of the plateau. There is one lodge there, and beavers were noted many times swimming about in the daytime. This is the happy result of its long seclusion, and the animals will always be unafraid so long as people take care not to disturb them. The roots of the water lilies would appear to be about the only readily available food there at the present time, although a few aspens have been recently cut a short distance back from the outlet, but nevertheless quite a long way from the open water and the lodge. There was a channel through the marsh grass to the dam; and this and other signs indicated that the lake is a way station between the Elk Creek and Lost Creek works.

The Yancey Meadows. The final result of the filling up of such a pond is a beaver meadow, and one cannot find a better example of this than the one near the old Yancey place (figure 48), where hay is now extensively cut and stacked for the winter feed of elk and buffalo, and the Rangers' horses ; and where bands of antelope licunt the margins of the broad lowland. Yet no longer ago than 1397 there were ponds here occupied by an active colony of beavers. Seton gives ('o9, pp. 455-472) a very full description of them, with a sketch map. About 1903 or 1904 the beavers abandoned the place, very possibly because they had exhausted the available supply of aspen, and it gradually changed to its present condition. I examined the stream for traces of the old dams, and though I found some of 
them, in most cases they had decayed and settled down to the level of the surrounding surface, showing that a comparatively short period of time is necessary to form a meadow. Farther down on the South Fork of Elk Creek, below Yanceys, are old dams whic? were broken through by high water twenty-five years ago.

Description of Beaver. As muskrats often inhabit beaver ponds, Park visitors unfamiliar with either animal should bear in mind that the adult beaver is much larger than the muskrat. In appearance a beaver is somewhat like a big, overgrown muskrat, with a broad, flat, scaly tail. Even the brown color of the fur is not at all unlike. a muskrat's. The total length of an adult beaver is about 42 inches, of which 16 inches is the tail,- the black, scaly portion being about 9 inches long and 4 inches wide. It will weigh 35 pounds and upward, even reaching 60 or more, although that is unusual. The hind feet are broad and webhed and the second toe has a curiously split nail. This latter is said to be used for combing the hair, but I do not know of anyone who has seen it so used. The forepaws are small, and the animal uses them much as hands, holding sticks when gnawing the bark from them, and also using them for digging up bottom mud and sod which are carried to any desired spot for building purposes, holding the material with the paws against the chin.

The fur is of two kinds, - the close, dense undercoat, and the long, outer guard hairs. These latter are usually plucked out in preparing the fur for the trade.

The huge incisors or front teeth are the tools with which the beaver does his wood cutting, and are eminently adapted to the purpose (figure 49). These teeth on the front side are composed mainly of a thin edge of very hard enamel, with a broad layer behind of relatively soft dentine. As the tooth is used the softer dentine wears away much faster than the enamel, so that there is always a sharp chisel edge on the front of the tooth. These teeth grow continuously during the life of the animal, and if by any accident one is broken or so injured that it does not oppose the one in the opposite jaw, the latter may grow out to such an extent as to seriously inconrenience the animal, if not to cause its death from inability to feed. The incisors are long, and the hidden portions have much curvature within the skull and lower jaw. Morgan gives the radius of the curvature of the upper incisors as one inch, and of the lower, one and three-quarters inches The front of the incisors is deep orange 


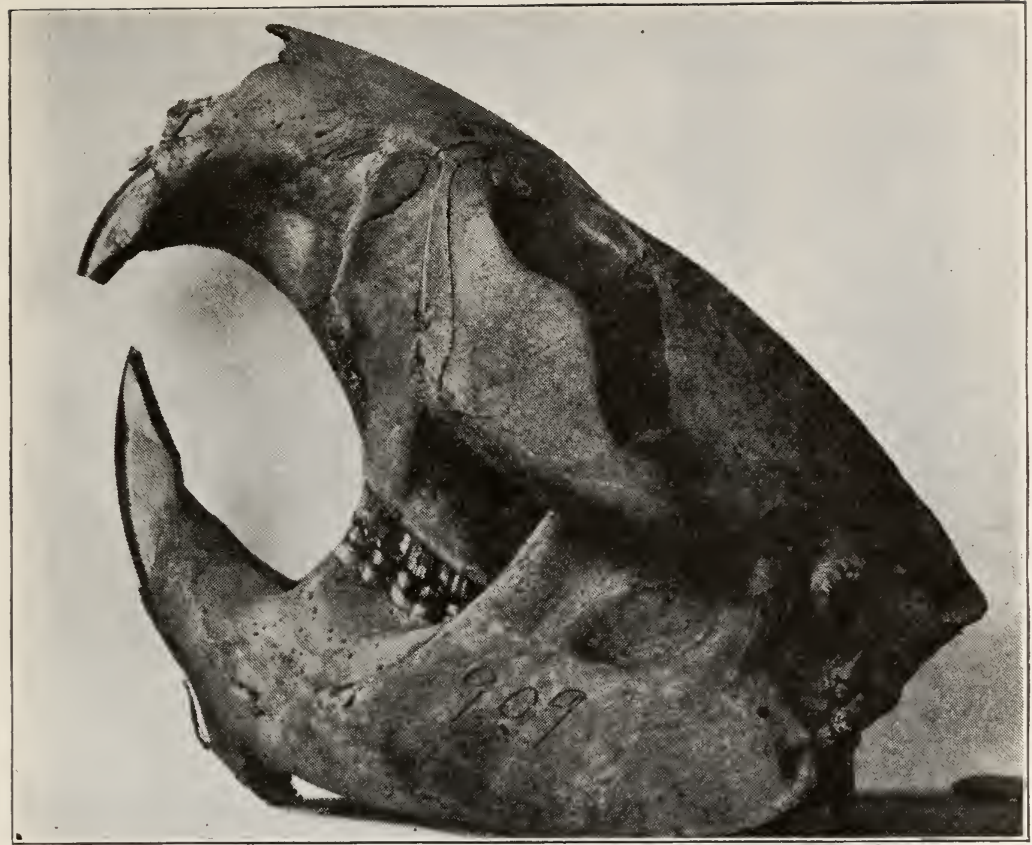

Fig. 49. Side view of skull of a beaver, showing the chisel-like character of the front teeth.

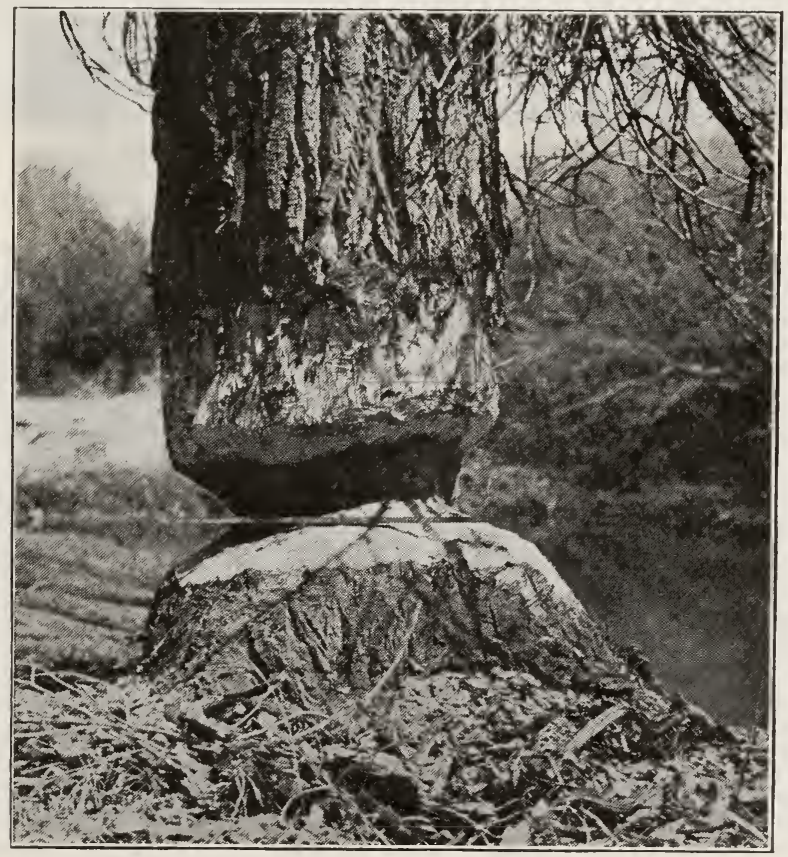

Fig. 50. Cottonwood tree partly cut by a beaver. The rule in the cut is 2 feet long. Trinchera Estate, Costilla County, Colorado, May II, I9I3. 


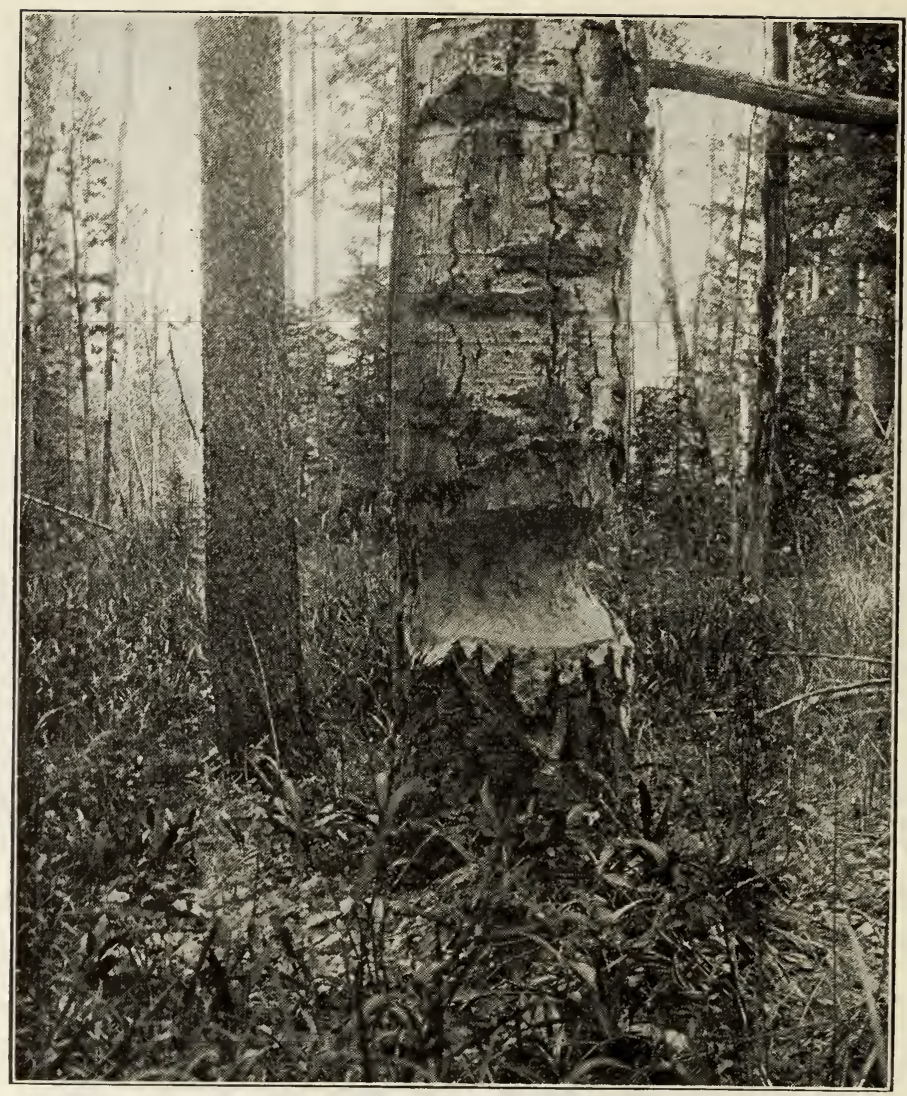

Fig. 5I. Large aspen partly cut by beaver. The tree measured 4.6 feet in circumference above the notch. Photographed July 22, I021.

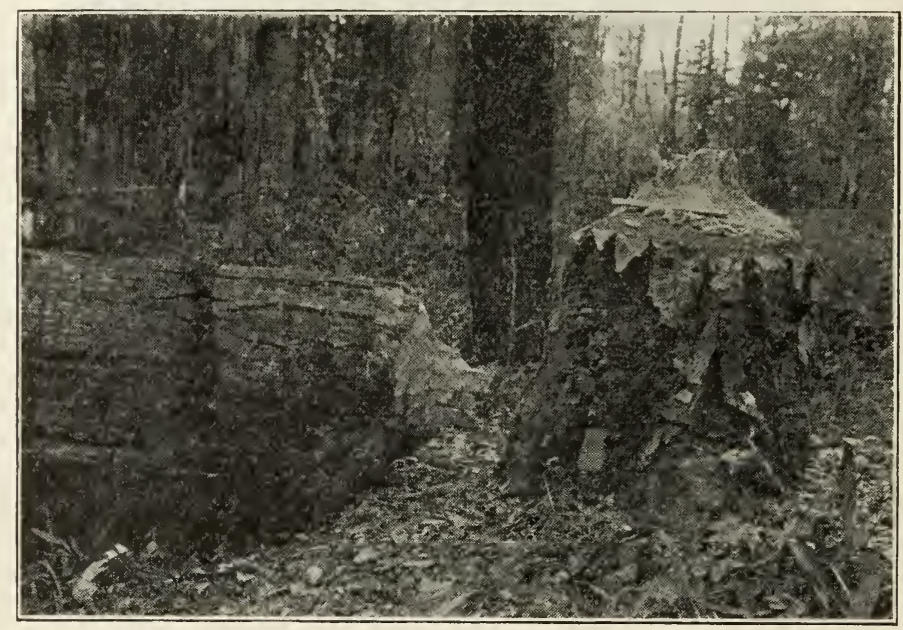

Fig. 52. The large aspen after it had been felled. Photographed September 4, I92I. It was still standing August 28. The rule on the stump is six inches long. 
in color. There are four teeth in the molar series on either side of each jaw, formed on much the same principle as the incisors, of vertical layers of enamel and dentine, the unequal wear of which gives a good grinding surface.

\section{Food of the Beaver}

The food of the beaver consists largely of the bark of deciduous trees, of which, in the Yellowstone and other parts of the west, aspen is the favorite. Willows and alders are also used, but not the bark of conifers, except occasionally. In summer other plants are also used; and I have noticed that they seemed especially fond of wild rose bushes. The beavers would go up on the hillside, near the Cooke City road, at Camp Roosevelt, and gather great bunches of these, holding them in their mouths and trailing them along down to the water. They sometimes ate them there by the bank, and sometimes they would swim with them to the lodge, diving and carrying them inside. Cow parsnip, choke cherry and various others of the plants growing along the shores of the ponds were also eaten. At Crescent Hill, near Yanceys, we saw beaver trails leading through the grass to where many thistles had been nipped off close to the ground. I saw grass carried to the lodge on several occasions, but there is a possibility that it might have been used for bedding.

One often sees in popular articles the statement that a beaver cuts a tree so as to make it fall in any desired direction. This is not true, as the animal makes the cut where most convenient to himself, and lets the tree fall as it may. On a steep hillside, and with trees up to six inches in diameter, in a great majority of cases the cut will be made on the uphill side, or on one side or the other, rarely on the downhill side, and all the cutting will be done from one side. From the way the cuts are made, one might suppose the trees would fall uphill, or to one side, but nearly all of them fall downhill, because they naturally lean that way.

When the trees are growing on level ground it is a different matter. They are usually cut quite evenly all round, especially if the tree is a large one. This is well illustrated in the case of the cottonwood in figure 50. A beaver may start to cut a tree, and then stop work, returning some time later to finish the job. This was finely illustrated in the case of a large aspen on the North Fork of Elk Creek, beyond Yanceys (figure 5I). This was first seen July 20 , and then had a considerable notch in it, not very freshly cut, but 
done recently. The tree was seen from time to time and on August 28 was still standing, but on September 4 was found to have been felled (figure 52). The tree measured 4.6 feet in circumference above the notch when standing.

Why does a beaver occasionally cut a tree and leave it where it has fallen, unused? Frankly, I do not know. I have in mind a lodgepole pine, about 4 feet in circumference, which we found on Tower Creek by the large spring, about two miles above Tower Fall. Beaver had cut it, and there it lay untouched. Across the stump lay another conifer which they had also cut, and likewise had not used. It looks almost like wanton waste. The big lodgepole pine was difficult cutting, being of harder wood, and the chips beside it were much smaller than those cut from aspens. I have found some of the latter nearly seven inches long, while the largest pine chips were about four inches long.

The height of stumps varies, ordinarily ranging from 6 to 20 inches. I found a few from 2 to 3 inches high, and a group of half a dozen from 3 to 4 feet high. One curious thing about these last is that the trunks were lying there unused. They appear to have been cut when deep snow was on the ground. In Colorado I have found the beaver active in the snow, as shown in figures 53 and 54 .

The largest stump cut by a beaver, of which I have personal knowledge, is a cottonwood in the Colorado Museum of Natural History, at Denver, which is 2 feet, 5.5 inches in diameter, and came from the Platte River above Denver. Director J. D. Figgins writes me that there is evidence of long intervals between the periods of cutting on this stump. Enos Mills mentions one stump of 3 feet, 6 inches in diameter, on the Jefferson River, Montana, near the mouth of Pipestone Creek.

Some measurements were made with the idea of ascertaining how far a beaver will go from water to cut a tree, but the results were rather inconclusive. At Crescent Lake old stumps were found 220 feet from the water's edge, but there were no trees farther away, and there seem to have been none formerly. This was the greatest distance found. At Lost Creek they foraged i75 feet away from the ponds, in this case to the limit of the aspens and the beginning of the pines (figure 45).

As cold weather approaches the beaver begins to make provision for the winter; so that besides seeing that the dam is in good order. 

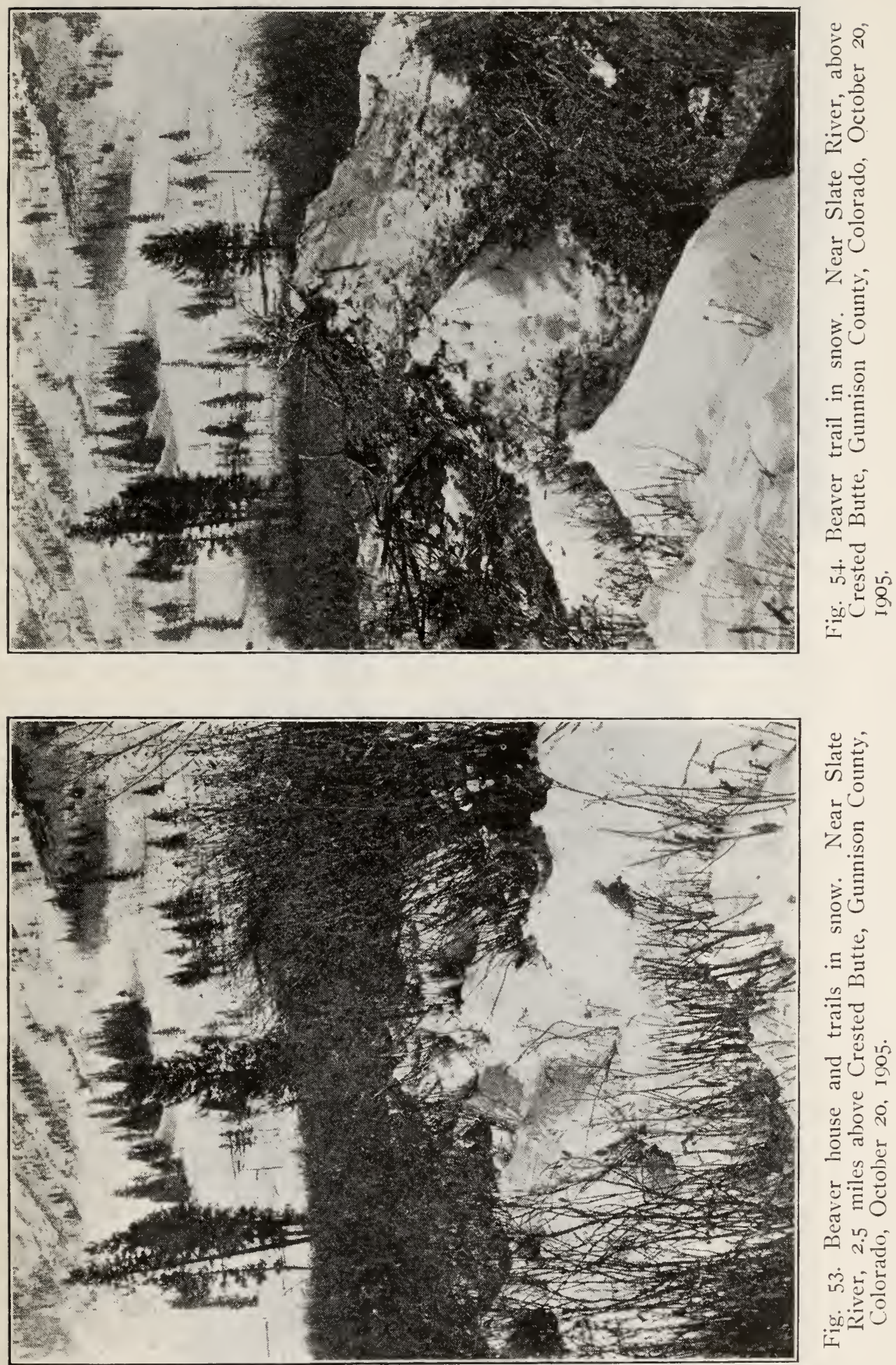

䒕

$-0$

일

능

$\dot{\Xi}$

ㅇ

के के

$\Xi \stackrel{0}{\Xi}$

$\because=$

䓀

تU。

0

जे

주

क

可:

당

ค เั่อ

$\dot{2}=$

ㄴํำ

$x=9$

诖 


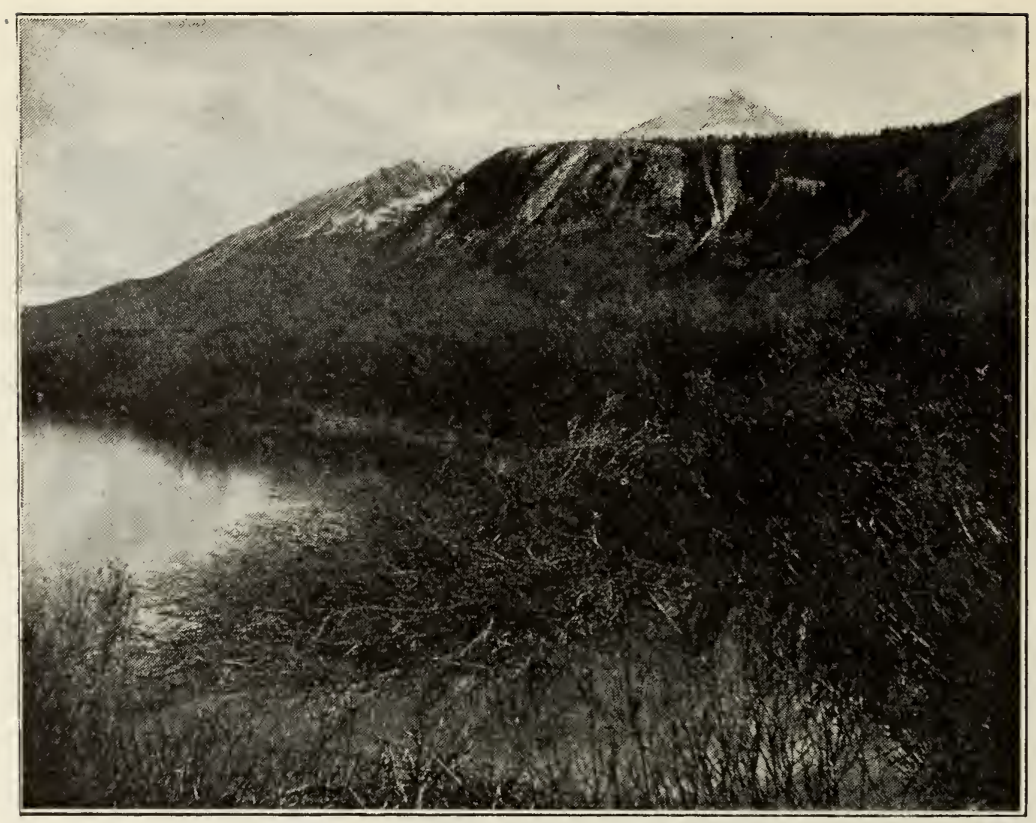

Fig. 5.5. Willow brush in beaver pond, cut and stored by beaver. Near Crested Butte, Colorado.

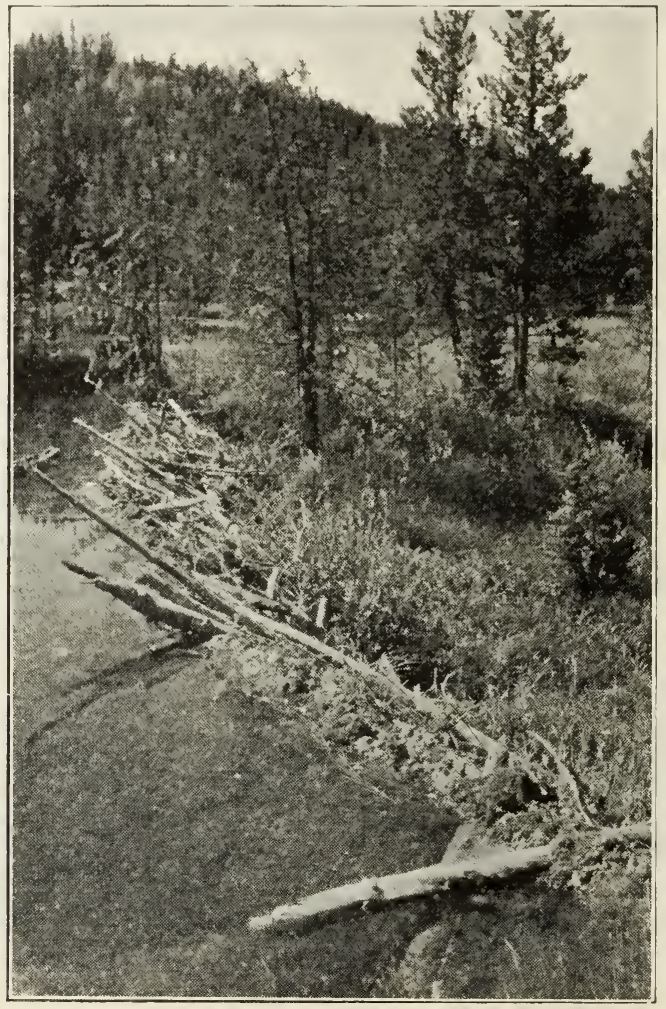

Fig. 56. A beaver dam near Brush Creek, Gunnison County, Colorado, showing pine logs projecting above the dam. An unusual occurrence. 
and the house well plastered with mud, it also begins to lay in a stock of provisions, in the shape of logs and branches of trees upon whose bark it feeds. Where aspens are available, these are the preferred sort, and willows and alders are likewise used, but the alders seem to be third choice. Where they are found, maple and birch are also made use of, and are much liked. Whatever species are used, the wood is taken to the pond and stored in the water. The small logs or poles are carried to the bottom and forced into the mud sufficiently to hold them until more is piled on them. While green aspen does not sink, as I have seen stated in a recent popular article on the beaver, but floats, it is very heavy, and doubtless after a time becomes water ogged, though one often sees freshly peeled green sticks floating in the pond where they have been discarded.

These food piles are usually at the lodge or close by. When the pond is covered with ice the owner comes out under water, cuts off a length and carries it indoors, where the bark is eaten, the peeled stick being carried out and left in the water. In Colorado I found a mass of stored willow brush extending roo feet along the shore, in water four feet deep, and piled up to the surface (figure 55). These willows were from three to eight feet long, and it will readily be seen that they represent much work as well as a large amount of food.

\section{Beaver Engineering}

Dams. Beavers use four different types of construction: dams, lodges, burrows and canals; but not every beaver uses them all, many living only in burrows, and probably are as well or better off for that. This happens when they are living on a stream too deep or swift for dams or lodges.

A dam is begun by laying twigs and branches on the bottom, butt ends upstream, and very likely forced into the bottom. These are covered with gravel or mud dug from the upstream side, stones also often being used. More twigs are then laid on top and covered, and thus the dam is built up until its top appears above the surface and a pond begins to form. The dam is carried up to the required height and the top is plastered with mud. The builders keep close watch on it, and are continually making repairs and additions. A beaver dam is never finished while the pond is occupied, its owners continually adding something to it. Perhaps the water may flow around the end. That is stopped with mud or sticks, whereupon the water in the pond rises so that the main dam has to be added in order to 
hold it, and then more water goes out around the ends and the process is repeated. I have but little doubt that many of the long, crooked dams which we see were thus built, not by designi but by this continual effort to stop the leaking over and around the dams.

Not all dams are built in streams. Some are built across gulches or on the sides of the valley, to control the water from springs. The largest pond I examined near Camp Roosevelt lies between Crescent Hill and a low ridge to the east (figure 42). It is 800 feet long by 340 feet wide, and is controlled by a comparatively short dam 165 feet long. This pond is supplied by springs, no surface water flowing into it except in the spring of the year when the snow is melting. There is quite a series of dams and small ponds below the large one, and several hundred feet downstream is a new dam which in time may make a fair sized pond, for the builders have selected the most suitable site, where the rather wide valley narrows somewhat, making it possible for a comparatively short dam to back up considerable water.

Also on Tower Creek, about two miles above Tower Falls, is an extensive series of ponds deriving their water supply from a very large spring on the flat ground scarcely one hundred feet from the stream and but a few feet above its level. A low dam had been built across the lower side of the spring, which is now about fifty feet in diameter, and measures eight feet deep.

Let us return to the building of the dam. On the lower face are placed many sticks, often those from which the bark has been eaten, or willow branches are used, and I have seen quite good sized logs utilized, whose ends projected high above the dam (figure 56). Whatever the material, these sticks are generally placed up and down the face, not transversely (figure 57). There is invariably, I think, a trail over the dam where the beavers cross, and this is always where the stream is, so that they may go down into the water from above.

It seems to me likely that in beginning a dam some of the branches are customarily laid across the current, for I have seen a number of dams which appear to have been thus underpinned. Moreover, when a dam is cut through, whether by man or by natural agencies, there are always the ends of sticks showing in the cross section thus exposed, indicating that they are deliberately laid crosswise (figure 58).

Dams are not always built completely across the stream. I recall a series of three dams in Colorado, none of which extended all the 


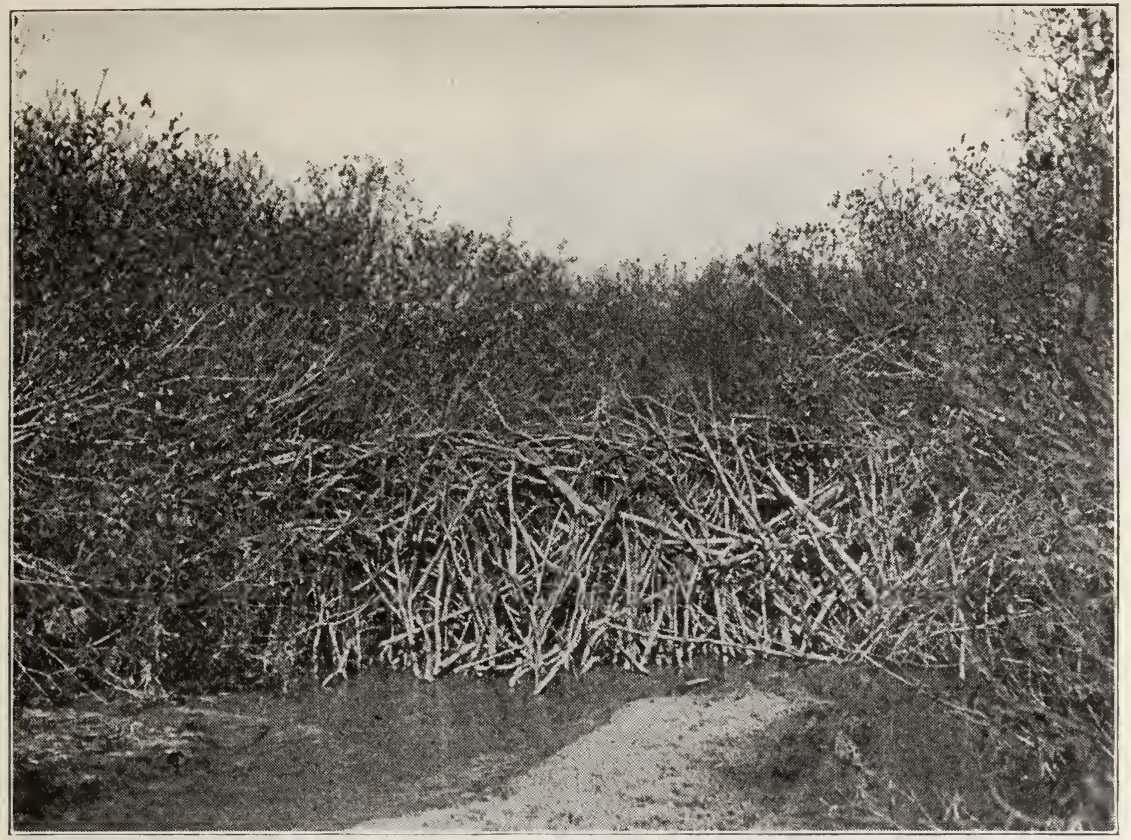

Fig. 57. Dam in which willow brush was largely used in construction, and with which the face is covered. A good example of this type. Monument Creek, El Paso, Colorado.

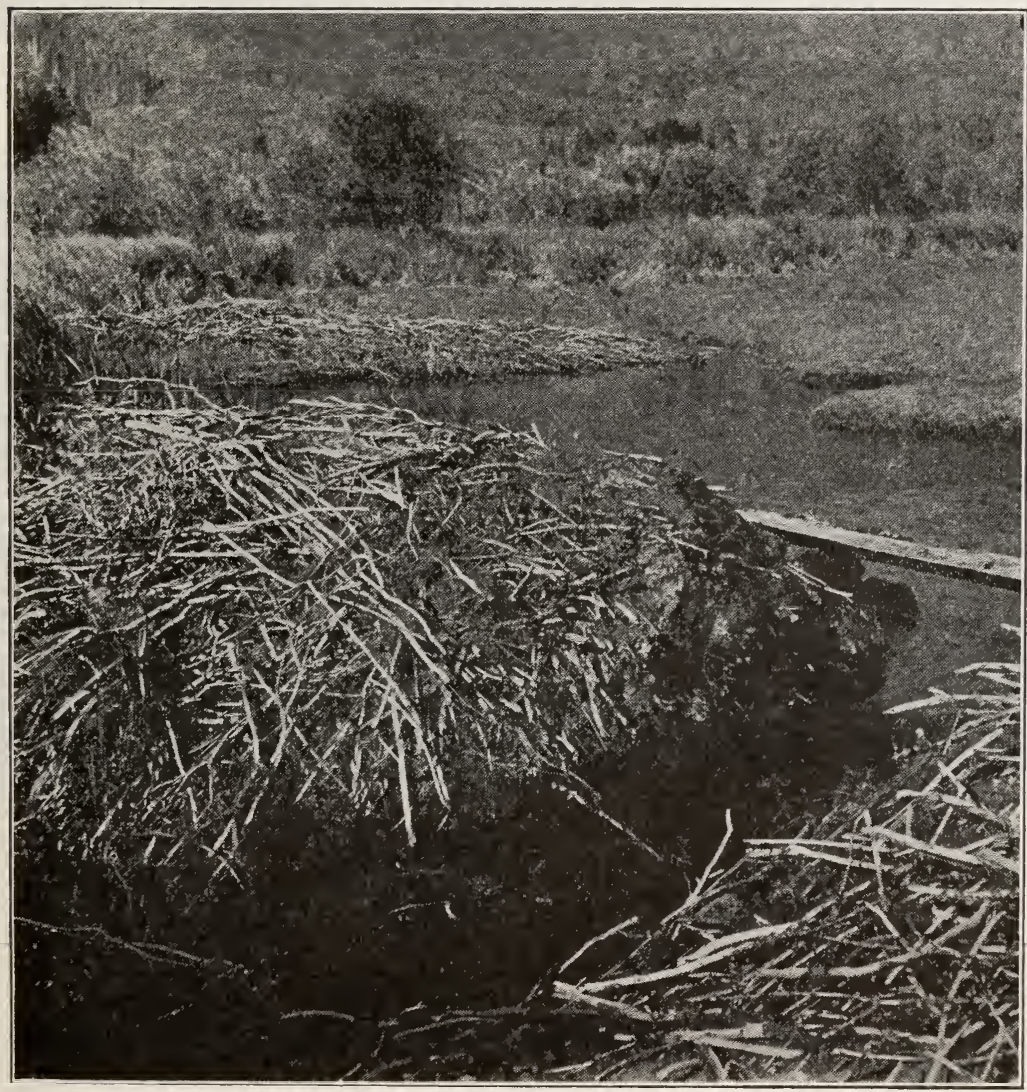

Fig. 58. Section of beaver dam, showing underpinning of sticks laid crosswise to the current. Near Crested Butte, Colorado. 


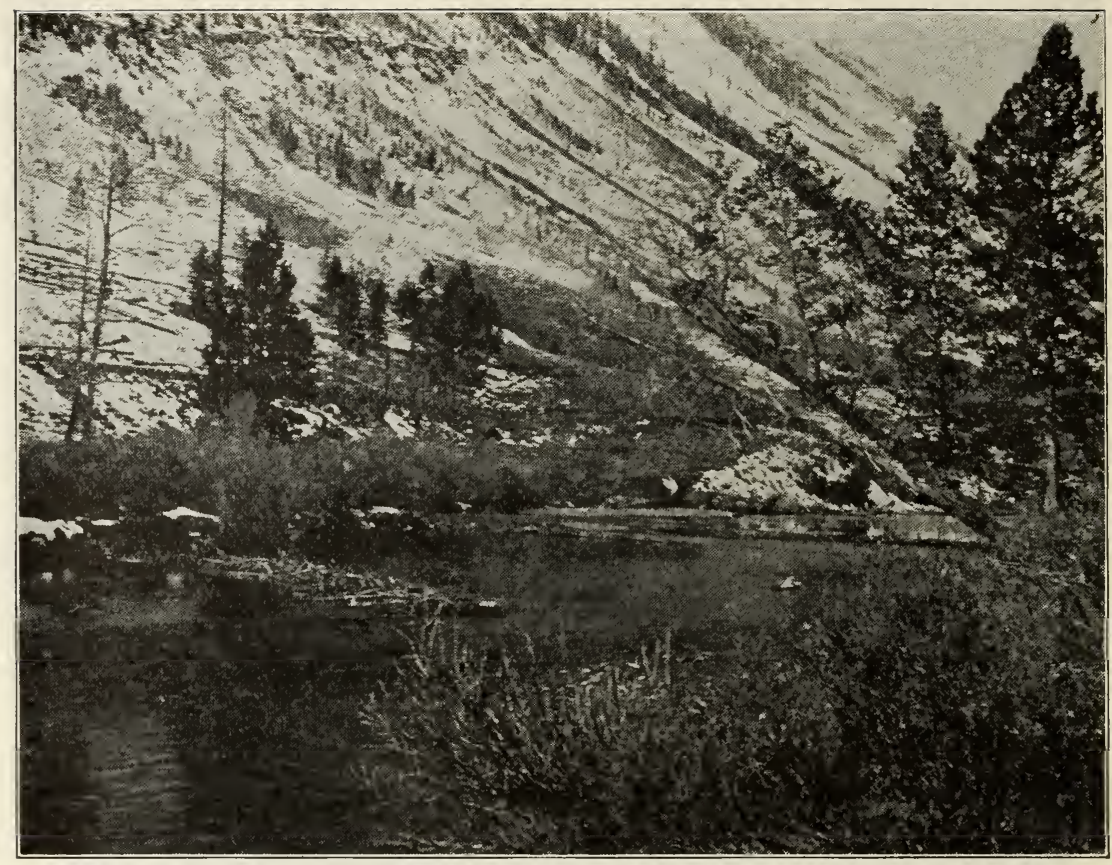

Fig. 59. Series of three beaver dams placed so as to form deep, quiet pools by the bank of the stream; on Slate River, Gunnison County, Colorado.

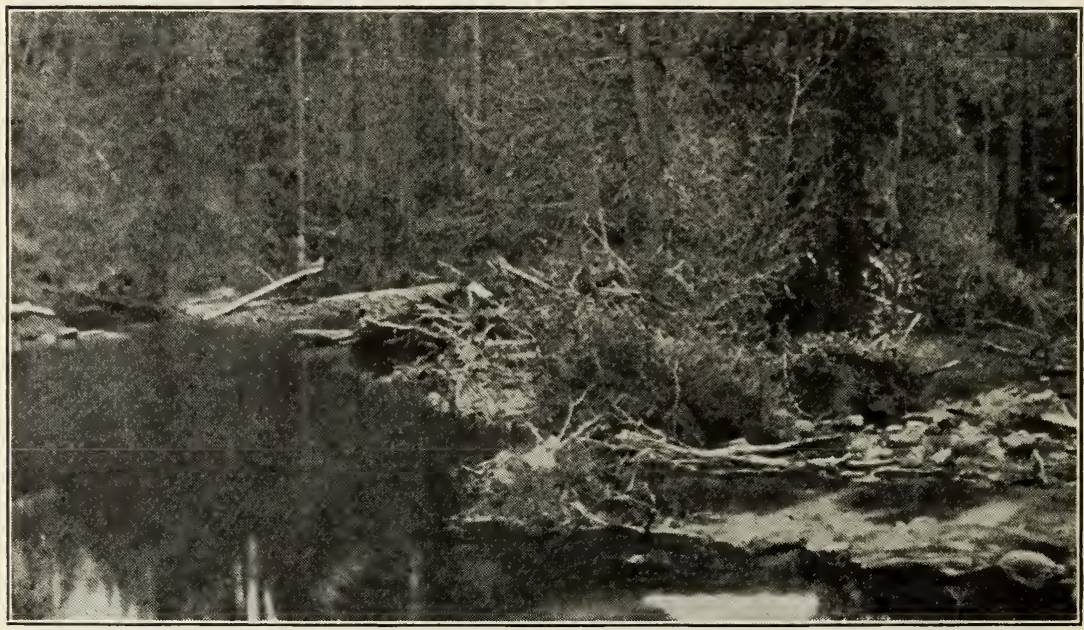

Fig. 6o. Diversion dam on Carnelian Creek, turning part of the stream onto the bank to supply ponds there. 
way across the river (figure 59). One of these was on one side, the other two on the other, and they were placed in such a manner as to deflect the water first to one side, then back again, forming deep, quiet pools. The diversion dam on Carnelian Creek, already described ( $\mathrm{p}$. 196), also illustrates this method of building (figure 6o).

As to the length of dams, they vary from a foot or two up to several hundred feet in length. The longest I measured was $35 \mathrm{C}$ feet long, on the North Fork of Elk Creek (figure 40). Seton speaks of one near Obsidian Cliff which he thought was 400 yards long. Enos Mills mentions one near Three Forks, Montana, 2, I40 feet long, mostly old, more than one-half of which was less than 6 feet high, two short sections being 23 feet wide at the base, 5 at the top and I4 high. Dams vary in height as in length, but I think they are rarely more than 6 feet high on the lower face, usually less. The thickness of the base varies firstly with the height, and secondly with the age of the dam, for as the material settles with age it tends to spread; and silt also settles at the base, so that even if the structure does not increase in height it may become wider.

If a dam is abandoned it gradually goes to ruin, yet many of the dams in Yellowstone Park and elsewhere have probably been abandoned at times for a number of years, and then repaired and reoccupied by a new colony of beavers.

Lodges. Lodges may be divided into two sorts, those built out in the water away from shore, and bank lodges. The former must have a foundation of some sort to start with, as a small island, or an elevation of the pond bottom sufficient for a beginning. Seemingly the lodge begins with a burrow, covered with mud and sod, on which sticks are laid, much as in building a dam. The interior is kept hollowed out as the work progresses, and the structure is more loosely built above the chamber to permit of ventilation. The floor is a few inches above water level, and is furnished with a bed of grass or shredded wood fiber. Dugmore says there are two levels to the floor, the lower for drying and feeding, the upper for a bed. There are usually at least two entrances to a house. In size they range from 8 feet to io feet in diameter and up. The largest house I have ever seen and measured is one in the large pond on Tower Creek previously mentioned (figure 6I). It is $2 \mathrm{I}$ by 24 feet in diameter, and 7 feet 3 inches above the water level. Five entrances were found. Dugmore mentions a house in Newfoundland 
that was 37 feet in its greatest diameter. An old house in a drained pond in Colorado, which I opened for examination, was 8 feet wide across the section, and io feet the other way (figure 62). The chamber was 2 feet wide, and extended back 4.5 feet. It was a foot high, but I suspect that the roof had settled. It was furnished with a bed of swamp grass. Dugmore gives the dimensions of one chamber as follows: 4 feet io inches long, four feet five inches wide, 2 feet $\mathrm{I}$ inch high, lower floor 4 inches above water, bed floor 6 inches higher.

Bank lodges are of two kinds, probably with intermediate stages between them. One sort is built against the bank, or with at least part of the structure projecting into the water, really a burrow extended and roofed over. The other kind is wholly within the bank, connected with the water by a burrow, and is simply a burrow enlarged and covered. A new one and an old one of this latter type were seen on Carnelian Creek. The former (figure 63) was 4 feet back from the stream bank, I5 inches above ground level, and 3 feet in diameter. An example of the first kind may be seen near Camp Roosevelt, below the Cooke City road, and the one in a pond a little lower down (figure 64) may possibly belong here. This last is the one which was occupied by a family of beavers in the summer of $192 \mathrm{I}$.

Burrows. Besides a lodge a beaver colony always has one or more burrows in the banks of a pond as additional refuges. One of these on the North Fork of Elk Creek was 3I feet long, which is probably unusual, the majority no cloubt being much shorter. One sometimes sees piles of logs and sticks in the water over the entrances to holes. These may in time develop into lodges. In Tower Creek I concluded that beaver were living in a log jam where there was a mass of débris high enough and solid enough to afford shelter for one or more of the animals, and no other place was found where they might be living. Also at another place on the same stream there was beside the bank a somewhat confused mass of sticks and logs which likewise appeared to be used as a dwelling. The creatures are undoubtedly very adaptable in their choice of dwelling places.

Canals. I am somewhat disposed to the belief that in some respects the canal is a higher engineering achievement than the dam. To deliberately plan and dig a channel in which to float logs to a pond, and not only that, but also to build dams in this channel to hold the water to a desired level, is an intelligent act. This is what 


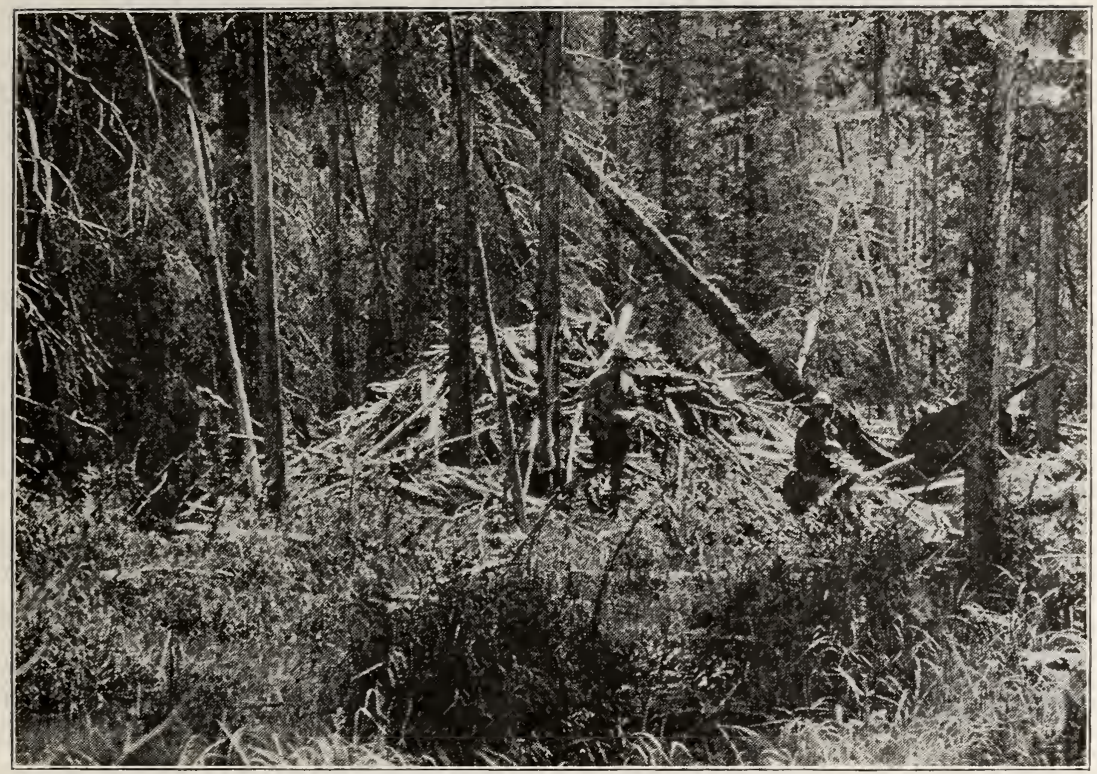

Fig. 6r. The big lodge adjacent to Tower Creek, in midst of heavy Engelmann spruce forest. Diameter 24 feet; height 7 feet, 3 inches above the water.

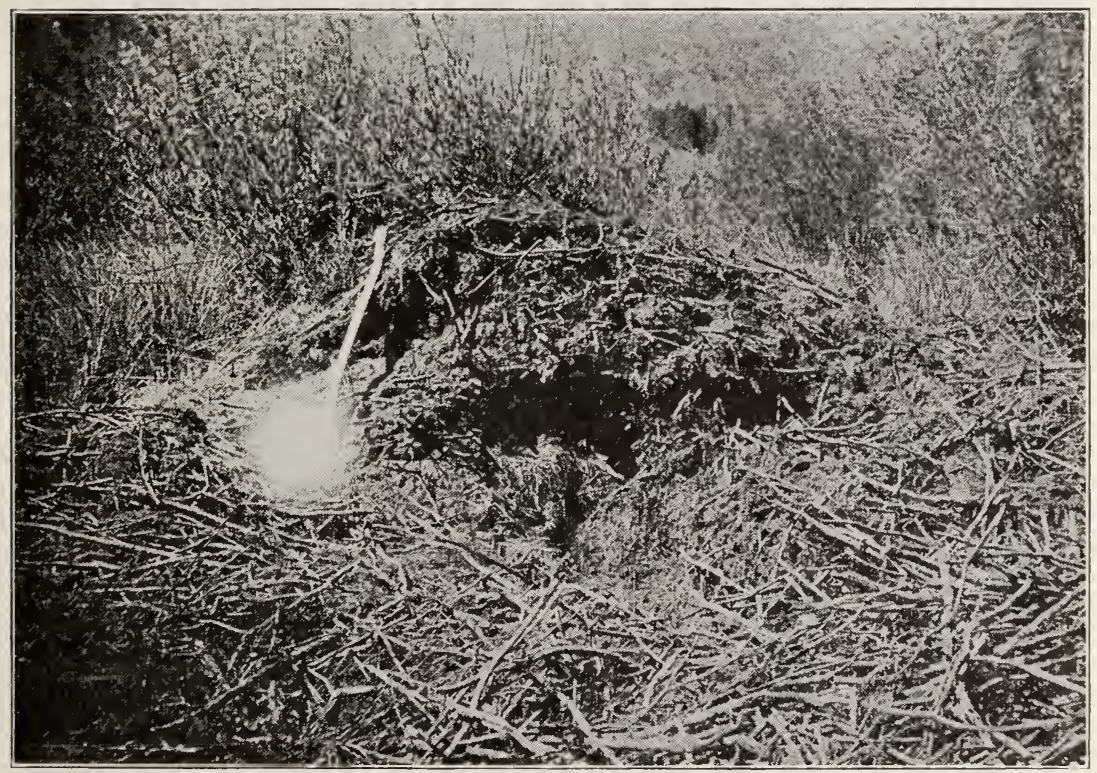

Fig. 62. Beaver house cut open, showing chamber and entrance. Near Crested Butte, Gunnison County, Colorado, September 5, 1902. 


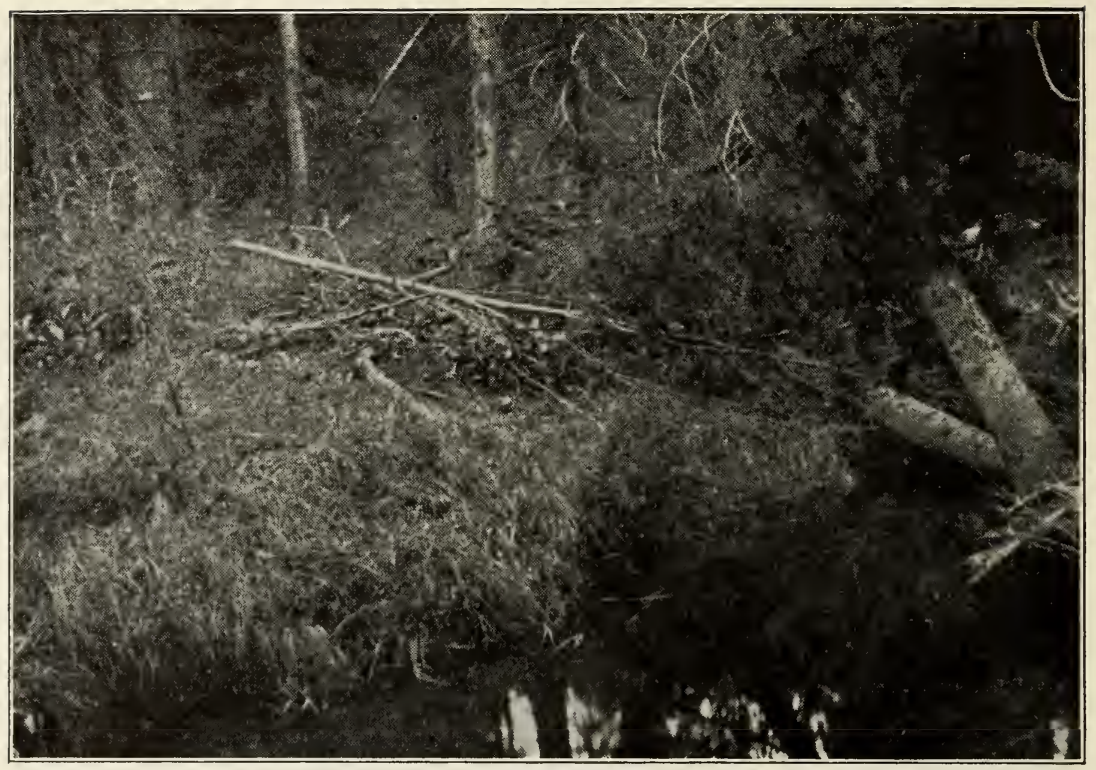

Fig. 63. Bank lodge on Carnelian Creek. Doubtless during high water in spring this would be flooded and untenable.

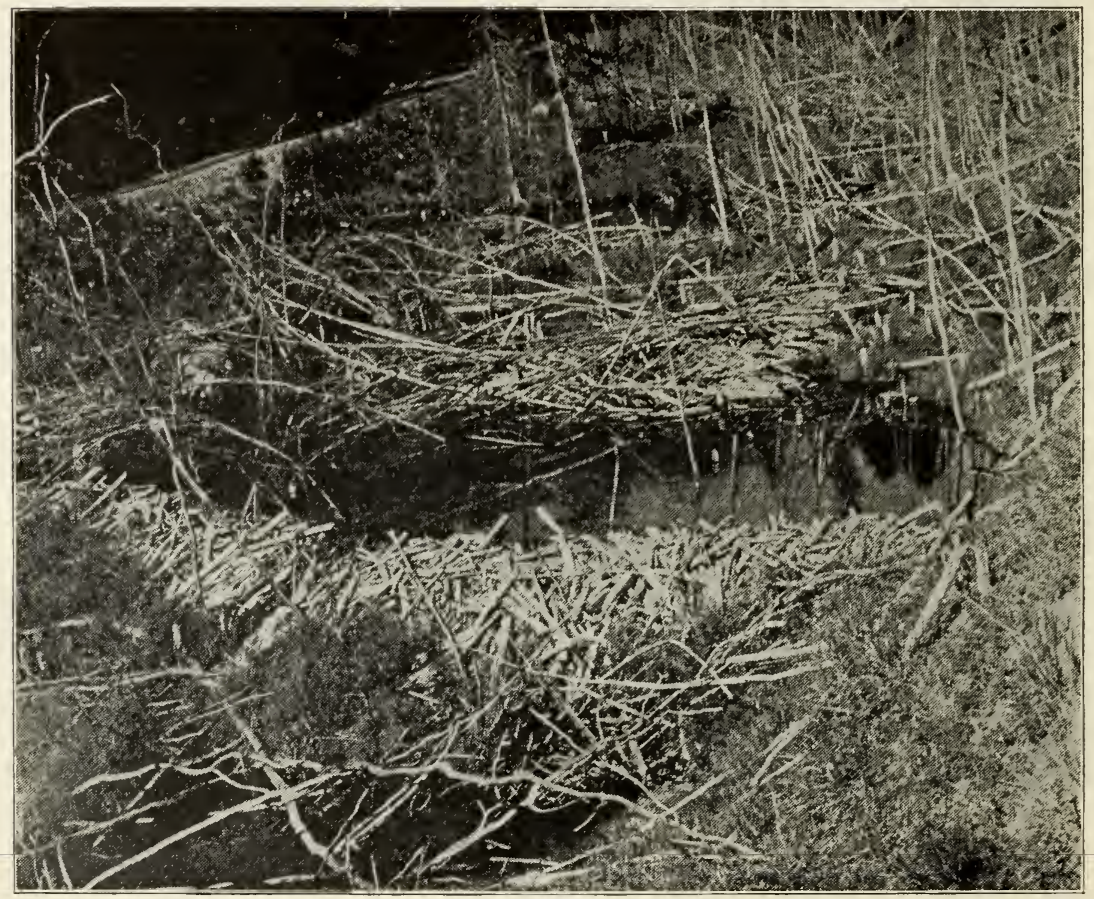

Fig. 64. Lodge in one of the ponds along Cooke City road. An example of a house lodge built against the bank. Occupied by at least eight beavers. 
the animals do, however, when the trees are at a distance from the shore, and the ground is flat enough to permit of carrying water in on a level, or controlling it by miniature dams. These ditches vary in width from $I$ to 4 feet, in depth from 8 inches to 2 feet, and the length may be but a few feet or very much more. Morgan mentions two in Michigan 523 and 579 feet long respectively. There is one on Tower Creek 90 feet long, and another I5O feet. Where the slope of the ground is such that the water would not maintain its level in the canal, a small dam is built to hold it back. Thus one of the Tower Creek canals was I7 feet long at the pond level from the shore to the lower end of the dam, and 23 feet to the upper side of the dam, and above this was another section of ditch 64 feet long (figure 65 ). The lower level of course obtained its water from the pond and was 15 inches deep (figure 66). The upper level was 9 inches deep and was supplied by drainage from the marshy ground about it. The canal was from 15 to 18 inches wide. The difference in level between the two parts was 20 inches. The long, gradual slope of the lower face of the dam facilitated dragging logs over it.

The other canal on Tower Creek was about half a mile up the creek from the preceding (figure 67). It was connected with the stream by a trail 23 feet long, and at the time of the examination this was 2 feet above the water level. This canal was from 3 to 4 feet wide, and 12 to 18 inches deep. The westerly bank was considerably lower than the other, and was being raised by mud dug from the bottom. The water supply was apparently derived from a spring at the landward end.

\section{Life History, Other Habits, and Enemies}

The number of young in a litter is from two to five, three or four being probably most common. They are born during May. I have not been able to learn at what time they first make their appearance outside the home nest; but most writers state that they appear in a very few weeks. At Camp Roosevelt I was sure there must be a family in the lodge in one of the ponds on the Cooke City road. There were two adults (figures 69, 70) and three yearlings seen almost every evening, but no smaller animals. I looked for them on my frequent visits, but it was not until August 22 that the young were seen, three, as large as big muskrats. Having a close look at one, I estimated its length as eighteen inches, while the yearlings 
were 30 inches or less. It is possible, of course, that these young were not allowed out of the lodge when people were about. They were certainly well able to take care of themselves when they did appear.

The bearer we watched were quite playful at times, at least the yearlings; and I also saw the kits play together once, but I spoiled the little game with the noise of a graflex shutter, and it ceased suddenly with a great splash. The game seemed to be to push each other about in the water. This appeared to be by placing cheeks and shoulders together, and pushing, and perhaps pulling, for they may have been holding with the forepaws. In any event two once rolled clear over in the water without losing their grip. My assistant said they made a noise like a young kitten, only sharper. Others have likened the voice of a bearer to that of a young puppy.

A beaver is undoubtedly at home in the water, even though its gait on land is a very awkward waddle. The hind feet alone are used in swimming, the tail not at all, except at times as a rudder. It is remarkable how quietly they can submerge and swim under water. One afternoon at the group of ponds by the Cooke City road a beaver was in shallow water eating some willow twigs it had cut. I was attempting to get into a position where I could get a picture, and was standing on some poles over the water. My movements disturbed the animal and it disappeared; but after an interval I saw it floating on the other side, watching me. To get to this place it had to pass under the poles on which I stood, and yet I had seen no indication of the passage. It went back and forth several times, always without detection.

During the summer a fishing party saw a bearer swim the Yellowstone in the canyon about half a mile below Elk Creek. It was working upstream and crossed several times. Whenever it came to very swift or rough water it dove and swam under water, coming to the surface again in a smooth place. It landed so close to a boy in the party that he laid a fishing rod over its back.

Beavers have a habit of occasionally making little piles of mud, round and flattened, and depositing their castoreum on them. This seems to serve in some way as a means of communication with other beavers. I found one such on upper Lost Creek when making my examination of that group of dams (figure 68). It was quite fresh when found, and must have been made one or two nights preceding, for we had been there just previously. It was a trifle more than a foot in diameter, and about four inches thick. 

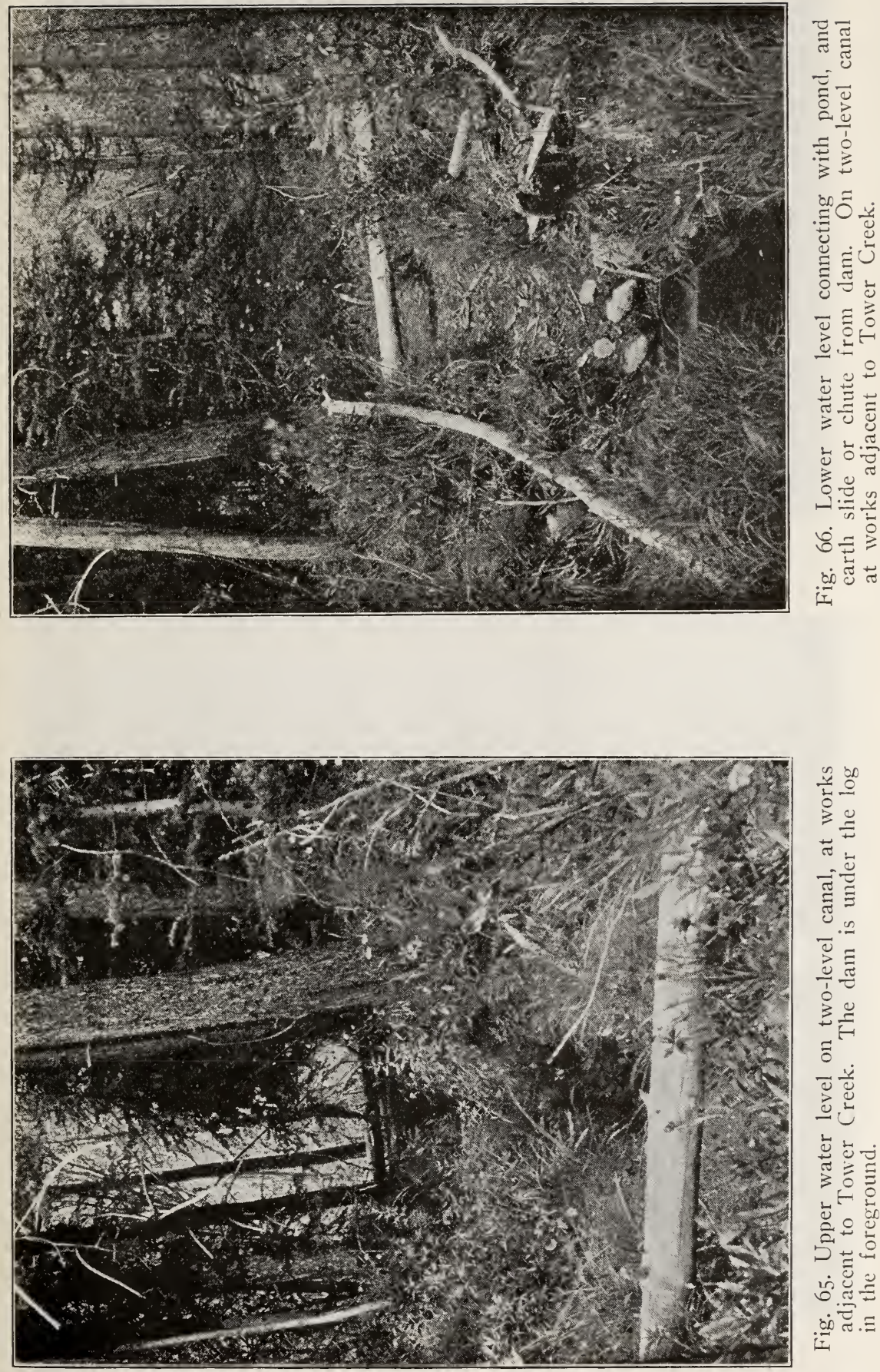

운용

$\geqslant 0$

त.

苂异

तु

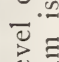

를

30

E

$\Xi$

¿

¿.

屯े

30

to

․․

2.

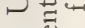

เ่.

में

江 


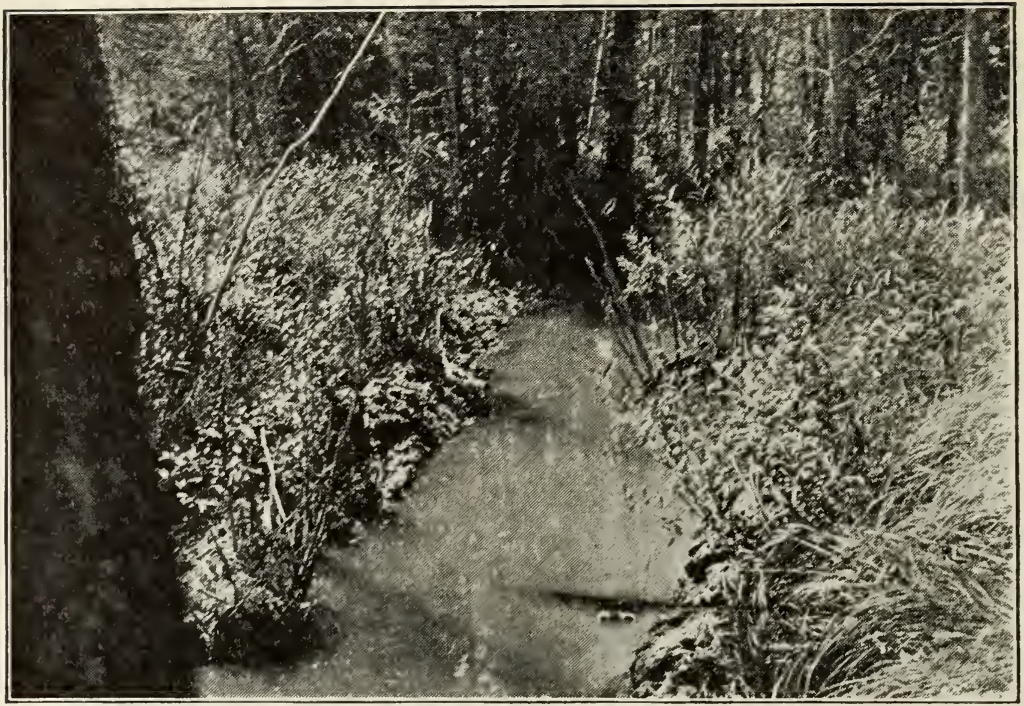

Fig. 67. Canal and mud banks half a mile above group of ponds at the big spring by Tower Creek.

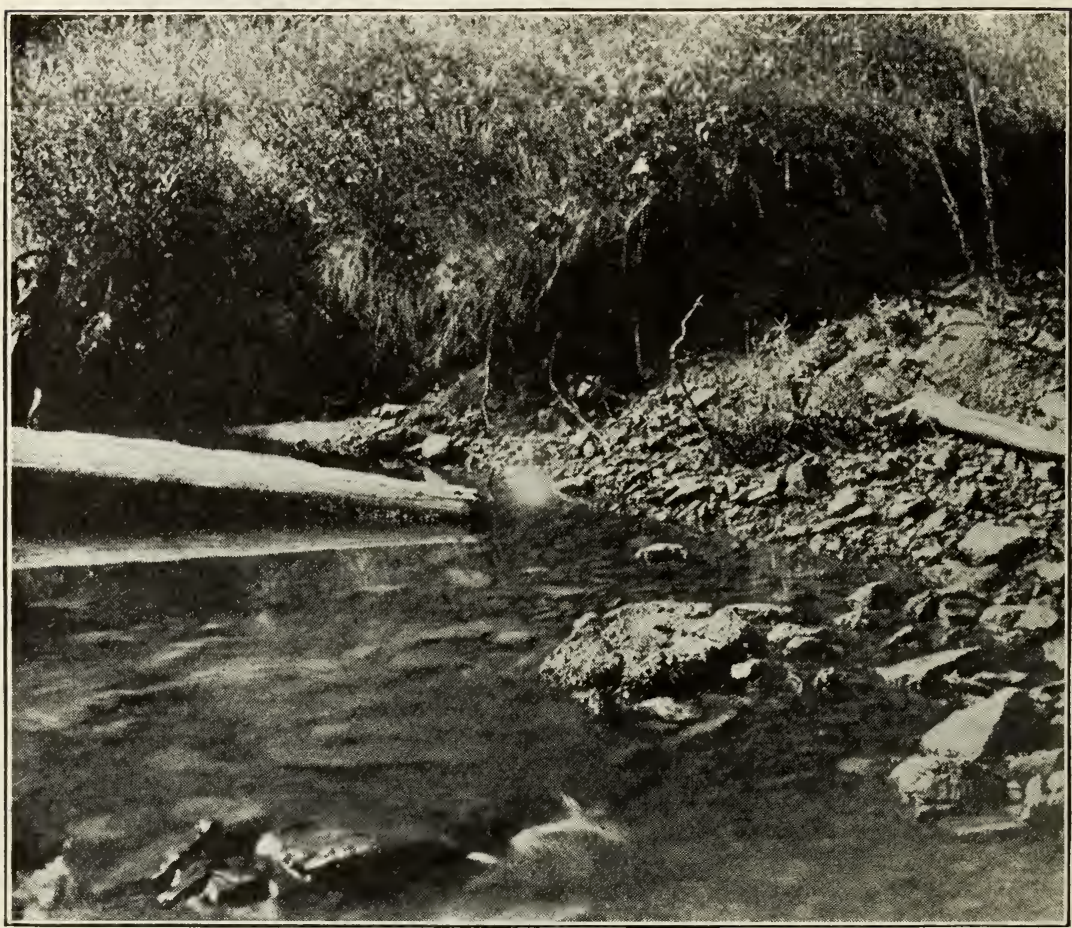

Fig. 68. Mud "sign heap" in upper Lost Creek; about a foot in diameter and four inches thick. The beavers deposit their castoreum on these piles, perhaps as a means of communication. 
Castoreum is a secretion found in two glands situated in the pubic region. It has a mild odor which appears to be attractive to other animals besides beaver. It is used as a bait in trapping the beavers themselves, a little of it being placed in such a position that the animal in coming to it is caught in the trap. It was formerly used as a medicine, still has a market value, and is a regular article of trade with the fur buyers under the name of " beaver castors."

Beavers have a number of enemies which never hesitate to pounce upon them whenever they get the chance. When the animal is on land its awkward gait makes it a comparatively easy prey to such predatory animals as mountain lions, bears, wolves, coyotes, or wolverines. Otters are also said to attack them. If that is the case, otters must be dreaded foes, for they are as much at home in the water as the beavers themselves.

\section{Value of Beaver to the Park Visitor}

The value of the beaver to the Park visitor is something rather difficult to put into words, but the creature has a real fascination for the intelligent tourist. Here is an animal of most interesting habits which was once to be found over the greater part of the United States but has since been exterminated from large areas, yet has left traces of its former presence in such place names as Beaver Brook, Creek, Kill, River, Lake, Falls, Hil!, Dam and Meadow. It can still be found in abundance in many parts of Yellowstone Park and the surrounding National Forests, affording opportunity for observing its habits and studying its works. Surely this is a valuable privilege for all who can visit the great Park.

It is worth while to observe in its native haunts a creature, whose fur has been an object of pursuit from the earliest days of North American settlement, and the search for which marked the beginning of the exploration and settlement of much of our western country, and which is still to be found undisturbed and free from molestation by the trapper.

Many a meadow in the thickly settled east was once a beaver pond. In the Park sanctuary the visitor from those regions may see meadows which only a few short years ago were ponds inhabited by colonies of beavers, but which are now yielding hay for the support of larger animals. Certainly an animal in which the great majority of tourists are interested is of value both to them and to the Park. The visitor can learn much about beaver ways without the trouble 


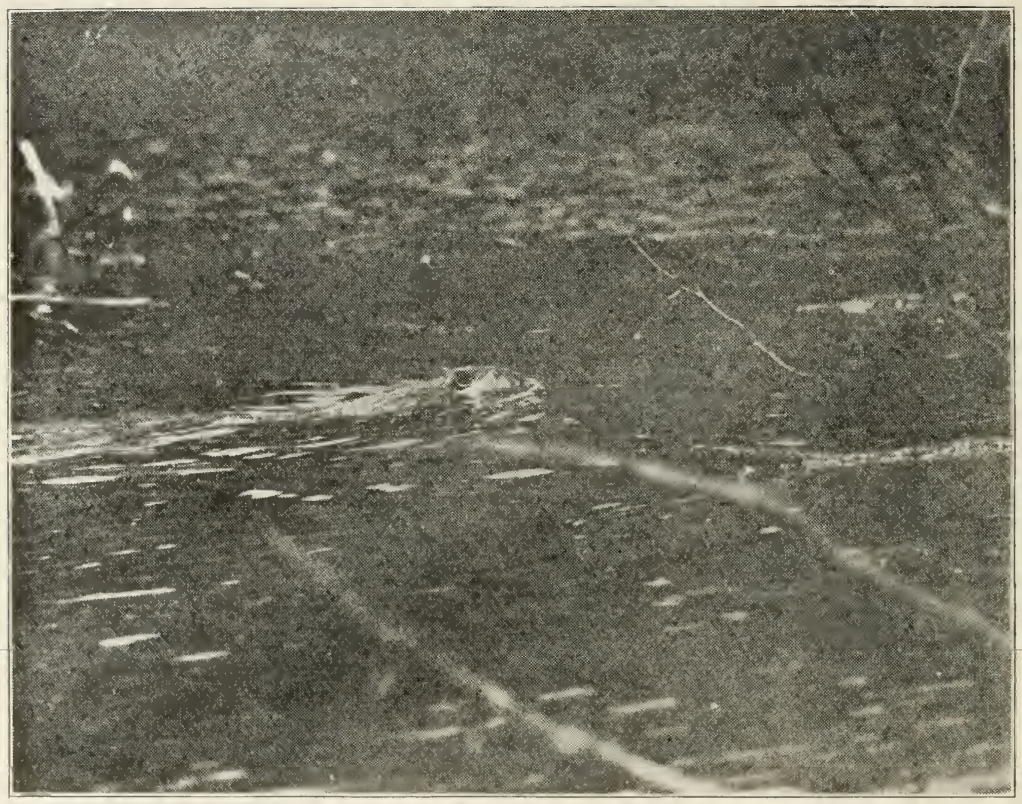

Fig. 69. Beaver swimming. Photographed at the large pond at Crescent Hill; about noon, July 22, I92I.

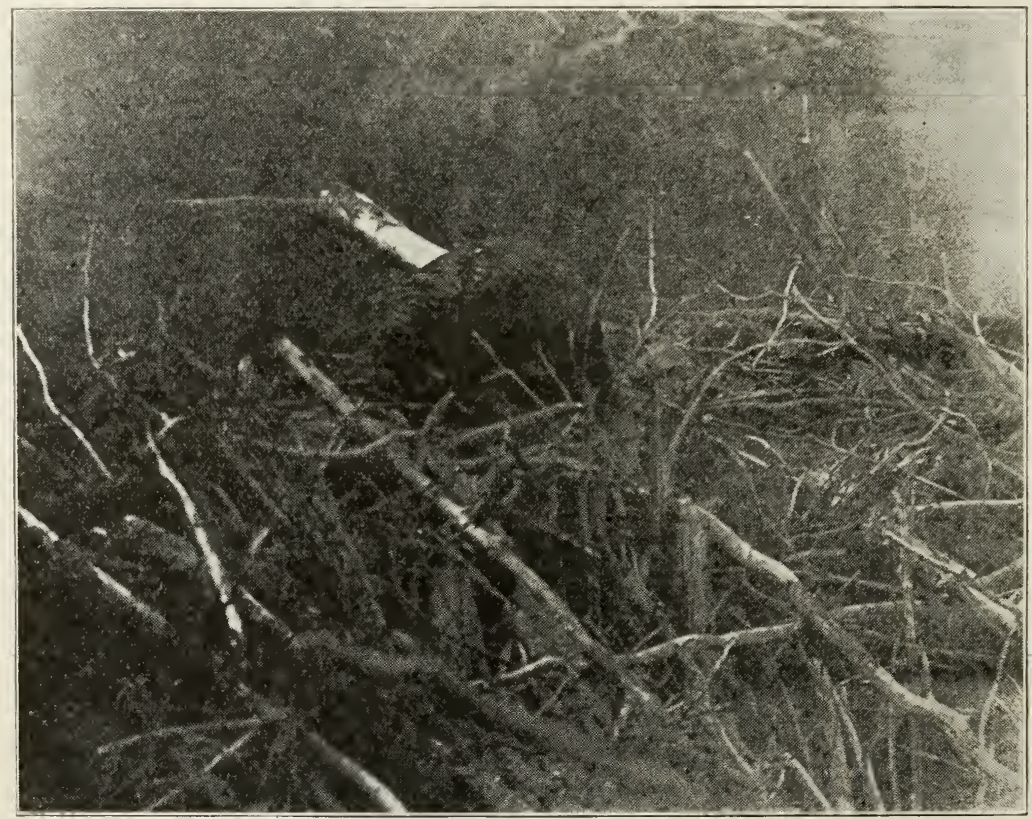

Fig. 70. Beaver crossing a dam. Photographed from beside the Cooke City road near Yellowstone River bridge in mid-afternoon. 
of long excursions into the wilderness,- how they fell trees for food and habitation, their marvelous engineering skill in damming streams and constructing lodges, their family life, and their relation to their surroundings. It is worth while to know these interesting facts at first hand rather than solely from pictures and books.

\section{References to Literature}

Dugmore, A. RadClyffe.

I9I4. The Romance of the Beaver. Pp. I-225. Phila. Johnson, Charles E.

1922. An Investigation of the Beaver in Hamilton and Herkimer Counties of the Adirondacks. Roosevelt Wild Life Bull., Vol. I, No. 2, pp. Iı7-I86.

Mills, Enos A.

I9I3. In Beaver World. Pp. I-228. Boston.

Morgan, Lewis H.

I868. American Beaver and His Works. Pp. I-330. Phila. Seton, E. T.

I909. Life Histories of Northern Animals. Vol. I, pp. I-673; Vol. 2, pp. 674-1267. New York.

I9I3. Wild Animals at Home. Pp. I-226. New York. WARREN, E. R.

1905. Some Interesting Beaver Dams in Colorado. Proc. Wash. Acad. Sci. Vol. 6, pp. 429-437. 


\section{WILD LIFE AND DEMOCRACY}

"Above all, the people, as a whole, should keep steadily in mind the fact that the preservation of both game and lesser wild life-by wise general laws, by the prohibition of the commercialism which destroys whole species for the profit of a few individuals, and by the creation of national reserves for wild life - is essentially a democratic movement. It is a movement in the interest of the average citizen, and especially in the interest of the man of small means. Wealthy men can keep private game preserves and private parks in which they can see all kinds of strange and beautiful creatures; but the ordinary men and women, and especially those of small means, can enjoy the loveliness and the wonder of nature, and can revel in the sight of beautiful birds, only on terms that will permit their fellow-citizens the like enjoyment. In other words, the people as a whole through the government, must protect wild life, if the people as a whole are to enjoy it. This applies to game also."

\section{Theodore Roosevelt and Edmund Heller. Life Histcries of African Game Animals. Vol. I, pp. I55-I56, I9I4.}




\section{THE ROOSEVELT WILD LIFE MEMORIAL}

\section{As a State Memorial}

The State of New York is the trustee of this wild life Memorial to Theodore Roosevelt. The New York State College of Forestry at Syracuse is a State institution supported solely by State funds, and the Roosevelt Wild Life Forest Experiment Station is a part of this institution. The Trustees are State officials. A legislative mandate instructed them as follows:

"To establish and conduct an experimental station to be known as 'Roosevelt Wild Life Forest Experiment Station,' in which there shall be maintained records of the results of the experiments and investigations made and research work accomplished; also a library of works, publications, papers and data having to do with wild life, together with means for practical illustration and demonstration, which library shall, at all reasonable hours, be open to the public." [Laws of New York, chapter 536. Became a law May Io, I9I9.]

\section{As a General Memorial}

While this Memorial Station was founded by New York State, its functions are not limited solely to the State. The Trustees are further authorized to cooperate with other agencies, so that the work is by no means limited to the boundaries of the State or by State funds. Provision for this has been made by the law as follows:

"To enter into any contract necessary or appropriate for carrying out any of the purposes or objects of the College, including such as shall involve cooperation with any person, corporation or association or any department of the government of the State of New York or of the United States in laboratory, experimental, investigative or research work, and the acceptance from such person, corporation, association, or department of the State or Federal government of gifts or contributions of money, expert service, labor, materials, apparatus, appliances or other property in connection therewith." [Laws of New York, chapter 42. Became a law March 7, I9I8.]

By these laws the Empire State has made provision to conduct forest wild life research upon a comprehensive basis, and on a plan as broad as that approved by Theodore Roosevelt himself.

\section{Form of Bequest to the Roosevelt Wild Life Memorial}

I hereby give and bequeath to the Roosevelt Wild Life Forest Experiment Station of The New York State College of Forestry at Syracuse, for wild life research, library, and for publication, the sum of..$\ldots \ldots \ldots$, or the following books, lands, etc. 



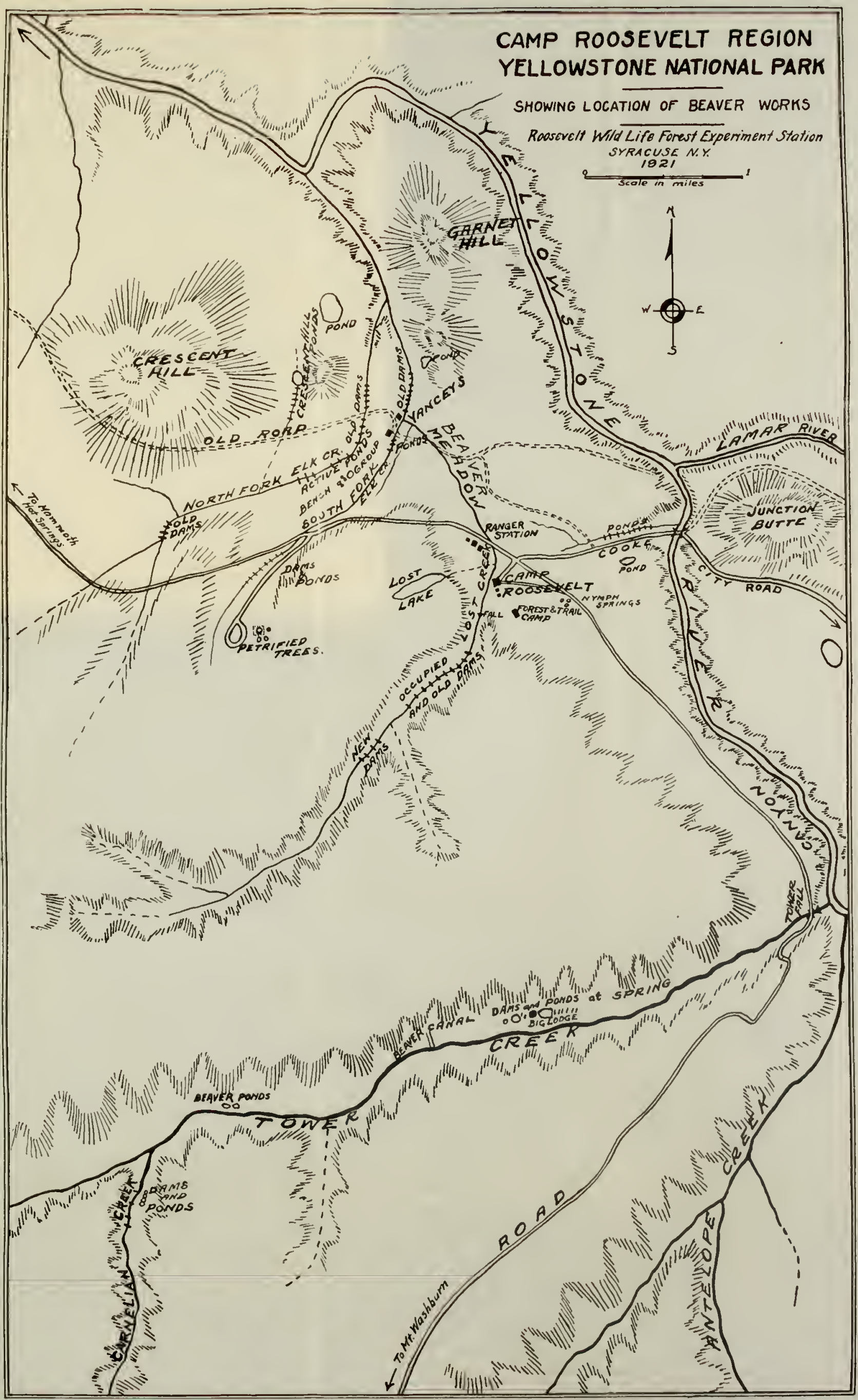




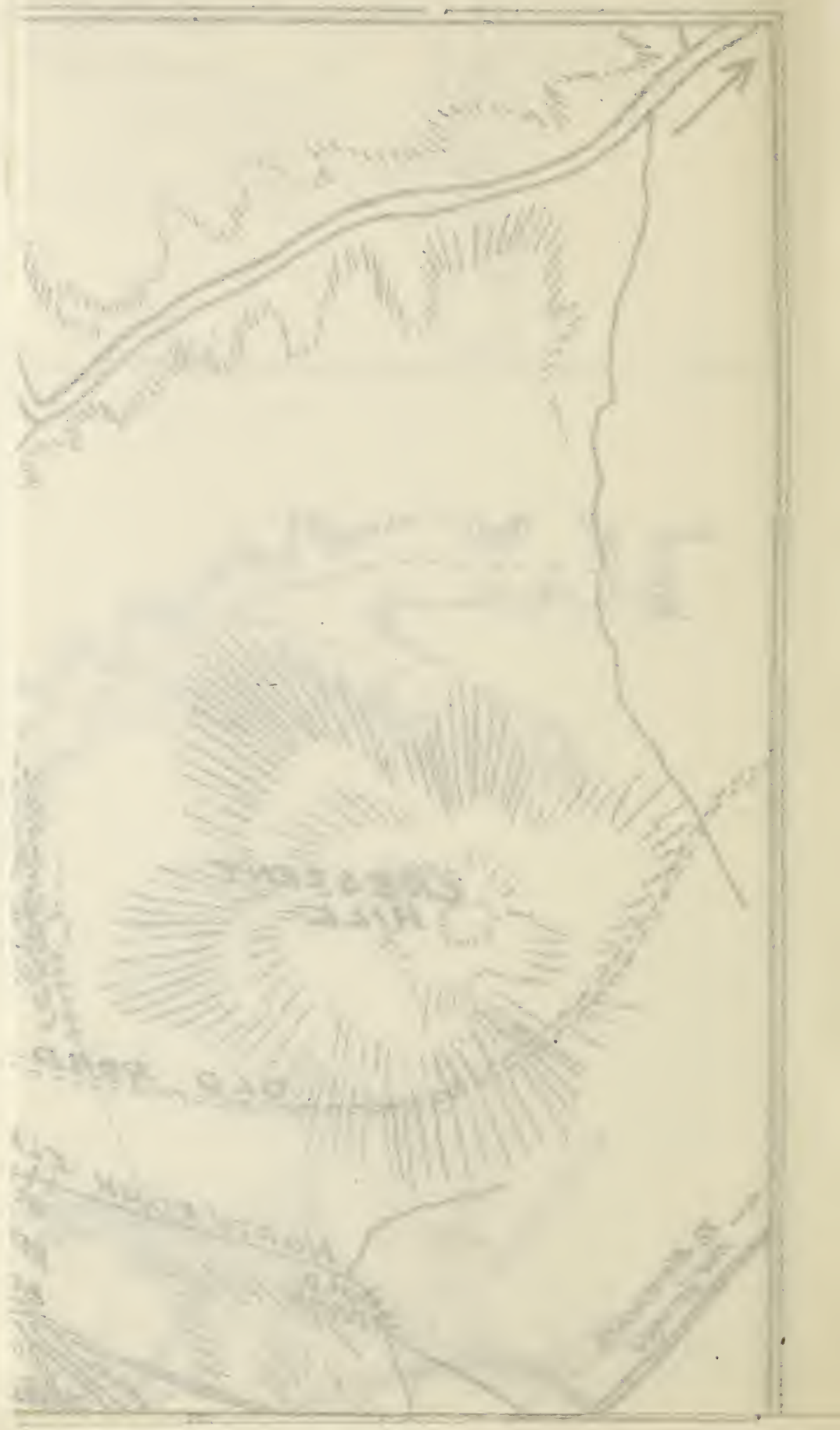


J. B. Lyon Company

PRINTERS AND BINDERS

1922 
